\title{
Linking genome content to biofuel production yields: a meta-analysis of major catabolic pathways among select $\mathrm{H}_{2}$ and ethanol-producing bacteria
}

Carlo R Carere ${ }^{1 \dagger}$, Thomas Rydzak ${ }^{2 \dagger}$, Tobin J Verbeke ${ }^{2}$, Nazim Cicek ${ }^{1}$, David B Levin ${ }^{1}$ and Richard Sparling ${ }^{2 *}$

\begin{abstract}
Background: Fermentative bacteria offer the potential to convert lignocellulosic waste-streams into biofuels such as hydrogen $\left(\mathrm{H}_{2}\right)$ and ethanol. Current fermentative $\mathrm{H}_{2}$ and ethanol yields, however, are below theoretical maxima, vary greatly among organisms, and depend on the extent of metabolic pathways utilized. For fermentative $\mathrm{H}_{2}$ and/or ethanol production to become practical, biofuel yields must be increased. We performed a comparative meta-analysis of (i) reported end-product yields, and (ii) genes encoding pyruvate metabolism and end-product synthesis pathways to identify suitable biomarkers for screening a microorganism's potential of $\mathrm{H}_{2}$ and/or ethanol production, and to identify targets for metabolic engineering to improve biofuel yields. Our interest in $\mathrm{H}_{2}$ and/or ethanol optimization restricted our meta-analysis to organisms with sequenced genomes and limited branched end-product pathways. These included members of the Firmicutes, Euryarchaeota, and Thermotogae.
\end{abstract}

Results: Bioinformatic analysis revealed that the absence of genes encoding acetaldehyde dehydrogenase and bifunctional acetaldehyde/alcohol dehydrogenase (AdhE) in Caldicellulosiruptor, Thermococcus, Pyrococcus, and Thermotoga species coincide with high $\mathrm{H}_{2}$ yields and low ethanol production. Organisms containing genes (or activities) for both ethanol and $\mathrm{H}_{2}$ synthesis pathways (i.e. Caldanaerobacter subterraneus subsp. tengcongensis, Ethanoligenens harbinense, and Clostridium species) had relatively uniform mixed product patterns. The absence of hydrogenases in Geobacillus and Bacillus species did not confer high ethanol production, but rather high lactate production. Only Thermoanaerobacter pseudethanolicus produced relatively high ethanol and low $\mathrm{H}_{2}$ yields. This may be attributed to the presence of genes encoding proteins that promote $\mathrm{NADH}$ production. Lactate dehydrogenase and pyruvate:formate lyase are not conducive for ethanol and/or $\mathrm{H}_{2}$ production. While the type(s) of encoded hydrogenases appear to have little impact on $\mathrm{H}_{2}$ production in organisms that do not encode ethanol producing pathways, they do influence reduced end-product yields in those that do.

Conclusions: Here we show that composition of genes encoding pathways involved in pyruvate catabolism and end-product synthesis pathways can be used to approximate potential end-product distribution patterns. We have identified a number of genetic biomarkers for streamlining ethanol and $\mathrm{H}_{2}$ producing capabilities. By linking genome content, reaction thermodynamics, and end-product yields, we offer potential targets for optimization of either ethanol or $\mathrm{H}_{2}$ yields through metabolic engineering.

\footnotetext{
* Correspondence: Richard_sparling@umanitoba.ca

${ }^{\dagger}$ Equal contributors

2Department of Microbiology, University of Manitoba, Winnipeg, MB, Canada R3T 5V6

Full list of author information is available at the end of the article
} 


\section{Background}

Fuel derived from waste-stream lignocellulosic biomass via consolidated bioprocessing is a renewable and carbon-neutral alternative to current petroleum-based fuels [1-3]. Consequently, considerable effort is being made to characterize species capable of efficiently converting lignocellulosic substrates into biofuels. An ideal biofuel producing microorganism should posses several key features, including: (i) high yields of the desired product, (ii) simultaneous utilization of sugars (cellulose, hemicellulose, pectin), and (iii) growth at elevated temperatures, and (iv) low product inhibition. Recent studies have focused on the characterization of numerous cellulose and hemicellulose degrading species of bacteria [4-6]. To fully exploit the biofuel producing potential of these organisms, several genomes have been sequenced and are now available for analysis (http://genome.jgi-psf. org/). While some hemicellulolytic or cellulolytic microorganisms are capable of hydrogen $\left(\mathrm{H}_{2}\right)$ or ethanol production via fermentation, end-product yields typically are far lower than their maximum theoretical values (4 $\mathrm{mol} \mathrm{H}_{2}$ or $2 \mathrm{~mol}$ ethanol per mol glucose) when cells are grown in pure culture. This is due to the presence of branched catabolic pathways that divert carbon and/or electrons away from a particular desired end-product [7]. Strategies that optimize yields for a single biofuel $\left(\mathrm{H}_{2}\right.$ or ethanol) can only be developed through a detailed knowledge of the relationships between genome content, gene and gene product expression, pathway utilization, and end-product synthesis patterns.

Given that our primary focus is to optimize $\mathrm{H}_{2}$ and/or ethanol yields, we restricted our meta-analysis to sequenced organisms with limited branched endproduct pathways (i.e. organisms that do not produce

Table $1 \mathrm{H}_{2}$ and ethanol producing organisms included in meta-analysis of end-product yields and genome content

\begin{tabular}{|c|c|c|c|c|c|c|}
\hline Organism & Synonyms & Taxon ID & GenBank \# & Sequencing Center & Phyla & C sources \\
\hline $\begin{array}{l}\text { Caldicellulosiruptor saccharolyticus } \\
\text { DSM } 8903\end{array}$ & & 351627 & NC_009437 & DOE Joint Genome Institute & $\mathrm{F}$ & $S, C, X$ \\
\hline $\begin{array}{l}\text { Caldicellulosiruptor besci } \\
\text { DSM } 6725\end{array}$ & $\begin{array}{l}\text { Anaerocellum thermophilum; } \\
\text { Z-1320 }\end{array}$ & 521460 & NC_012036 & DOE Joint Genome Institute & $\mathrm{F}$ & $S, C, X$ \\
\hline $\begin{array}{l}\text { Pyrococcus furiosus } \\
\text { DSM } 3638\end{array}$ & & 186497 & AE009950 & Univ of Maryland, Univ of Utah & $E$ & $S, C, X$ \\
\hline $\begin{array}{l}\text { Thermococcus kodakaraensis } \\
\text { KOD1 }\end{array}$ & & 69014 & NC_006624 & $\begin{array}{l}\text { Kwansei Gakuin Univ, } \\
\text { Kyoto University }\end{array}$ & $E$ & $S$ \\
\hline $\begin{array}{l}\text { Thermotoga neapolitana } \\
\text { DSM } 4359\end{array}$ & $\begin{array}{c}\text { ATCC 49049; JCM 10099; } \\
\text { NS-E }\end{array}$ & 309803 & NC_011978 & Genotech corp. & $\mathrm{T}$ & $\mathrm{S}, \mathrm{C}$ \\
\hline $\begin{array}{l}\text { Thermotoga petrophila } \\
\text { RKU-1 }\end{array}$ & & 390874 & NC_009486 & DOE Joint Genome Institute & $\mathrm{T}$ & $S, C, X$ \\
\hline $\begin{array}{l}\text { Thermotoga maritima } \\
\text { MSB8 }\end{array}$ & DSM 3109 & 243274 & NC_000853 & J. Craig Venter Institute & $\mathrm{T}$ & $S, C, X$ \\
\hline $\begin{array}{l}\text { Caldanaerobacter subterraneus } \\
\text { subsp. tengcongensis } \\
\text { MB4 }\end{array}$ & $\begin{array}{c}\text { Thermoanaerobacter } \\
\text { tencongensis }\end{array}$ & 273068 & NC_003869 & $\begin{array}{l}\text { Beijing Genomics Institute, } \\
\text { The Institute of Microbiology, } \\
\text { China }\end{array}$ & $\mathrm{F}$ & $S$ \\
\hline $\begin{array}{l}\text { Ethanoligenens harbinense } \\
\text { YUAN-3 T }\end{array}$ & DSM 18485 & 663278 & NC_014828 & DOE Joint Genome Institute & $\mathrm{F}$ & $\mathrm{S}, \mathrm{C}$ \\
\hline $\begin{array}{l}\text { Clostridium cellulolyticum } \\
\mathrm{H} 10\end{array}$ & & 394503 & NC_011898 & DOE Joint Genome Institute & $\mathrm{F}$ & $S, C, X$ \\
\hline $\begin{array}{l}\text { Clostridium phytofermentans } \\
\text { ISDg }\end{array}$ & ATCC 700394 & 357809 & NC_010001 & DOE Joint Genome Institute & $\mathrm{F}$ & $S, C, X$ \\
\hline $\begin{array}{l}\text { Clostridium thermocellum } \\
\text { ATCC } 27405\end{array}$ & DSM 1237 & 203119 & NC_009012 & $\begin{array}{l}\text { DOE Joint Genome Institute, } \\
\text { University of Rochester }\end{array}$ & $\mathrm{F}$ & $S, C, X$ \\
\hline $\begin{array}{l}\text { Clostridium thermocellum } \\
\text { DSM } 4150\end{array}$ & JW20 & 492476 & ABVG00000000 & DOE Joint Genome Institute & $\mathrm{F}$ & $S, C, X$ \\
\hline $\begin{array}{l}\text { Thermoanaerobacter pseudethanolicus } \\
\text { 39E }\end{array}$ & ATCC 33223 & 340099 & NC_010321 & DOE Joint Genome Institute & $\mathrm{F}$ & $S, X$ \\
\hline $\begin{array}{l}\text { Geobacillus thermoglucosidasius } \\
\text { C56-YS93 }\end{array}$ & & 634956 & NC_015660 & DOE Joint Genome Institute & $\mathrm{F}$ & $S$ \\
\hline $\begin{array}{r}\text { Bacillus cereus } \\
\text { ATCC } 14579\end{array}$ & DSM 31 & 226900 & NC_004721 & Integrated Genomics Inc. & $\mathrm{F}$ & $S$ \\
\hline
\end{tabular}

National Center for Biotechnology Information taxon IDs, GenBank accession numbers, corresponding sequencing centers responsible for the generation of the genome sequences data analyzed in this study are provided. Phyla (F; Firmicutes: E;Euryarchaeota: T; Thermotogae), and polymeric carbon sources degraded (S; starch: C; cellulose: $\mathrm{X}$; xylose) by each organism are indicated). 
butyrate, butanol, propionate, propanol, and acetoin) for which end-product data was available. These included members of the Firmicutes (Clostridium, Caldicellulosiruptor, Thermoanaerobacter, Caldanaerobacter, Ethanoligenens, Geobacillus, and Bacillus species), Euryarchaeota (Thermococcus and Pyrococcus species), and Thermotogae (Thermotoga species). A list of species analyzed and corresponding GenBank accession numbers are summarized in Table 1. With the exception of Caldanaerobacter subterraneus subsp. tengcongensis, Thermoanaerobacter pseudethanolicus, Pyrococcus furiosus, Geobacillus thermoglucosidasius, and Bacillus cereus, all organisms were capable of cellulose and/or xylan saccharification.

We focused on the various metabolic branches involved in pyruvate formation from phosphoenolpyruvate (PEP) and subsequent catabolism of pyruvate into end-products. Although studies comparing the $\mathrm{H}_{2}$ and ethanol-producing potential of several cellulose degrading bacteria have been previously published [8-10], a comprehensive comparison of the major biofuel producing pathways at the genome level has not yet been reported. Here we present a comparison of the genes encoding proteins involved in (i) pyruvate metabolism, (ii) ethanol synthesis, and (iii) $\mathrm{H}_{2}$ metabolism, in order to rationalize reported end-product yields. Results indicate that the presence or absence of specific genes dictating carbon and electron flow towards end-products may be used to infer end-product synthesis patterns and help develop informed metabolic engineering strategies for optimization of $\mathrm{H}_{2}$ and ethanol yields. Furthermore, certain genes may be suitable biomarkers for screening novel microorganisms' capability of producing optimal $\mathrm{H}_{2}$ or ethanol yields, and may be suitable targets for metabolic engineering strategies for optimization of either ethanol or $\mathrm{H}_{2}$ yields

\section{Methods}

\section{Comparative analysis of genome annotations}

All sequence data and gene annotations were accessed using the Joint Genome Institute's Integrated Microbial Genomes (IMG) database [11]. Gene annotations presented in this paper reflect the numbering of the final assembly or most recent drafts available (July, 2012). Comparative analyses were performed using the IMG database. In brief, analyses of all genomes (Table 1) were conducted using three annotation databases independently: i) Clusters of Orthologs Groups (COGs) [12], ii) KEGG Orthology assignments (KO) [13], and (iii) TIGRFAMs [14]. Genes identified using a single database were cross-referenced against the others to identify genes of interest. Functional annotations of the identified genes were evaluated on a case-by-case basis and decisions regarding the annotation accuracy were made using a combination of manual analysis of genomic context, literature searches, and functional prediction through RPS-BLAST using the Conserved Domain Database website [15].

Hydrogenases were classified based on phylogenetic relationships of hydrogenase large subunits according to Calusinska et al. [16]. The evolutionary history was inferred using the Neighbor-Joining method [17]. The bootstrap consensus tree inferred from 1000 replicates is taken to represent the evolutionary history of the taxa analyzed [18]. The evolutionary distances were computed using the Poisson correction method [19] and are in the units of the number of amino acid substitutions per site. The analysis involved 50 amino acid sequences. All ambiguous positions were removed for each sequence pair. There were a total of 863 positions in the final dataset. Evolutionary analyses were conducted in MEGA5 [20]. Thermodynamic calculations were performed using values provided by Thauer et al. [21] and the CRC Handbook of Chemistry and Physics [21,22]. BioEdit v.7.0.9.0 [23] was used to perform sequence alignments.

\section{Results and discussion}

Survey of End-product yields

A literature survey of end-product yields (normalized to mol end-product per mol hexose equivalent) of the species surveyed in this study is summarized in Table 2. While it is difficult to perform a direct comparison of end-product yields from available literature due to different growth conditions employed (ex. growth substrate, carbon loading, reactor conditions, etc.), and further difficult to validate these data due to incomplete endproduct quantifications and lack of corresponding carbon balances and oxidation/reduction $(\mathrm{O} / \mathrm{R})$ ratios, it still provides a good approximation of molar endproduct yields based on substrate utilization. Calculated end-product yields reveal that the Caldicellulosiruptor, Pyrococcus, Thermococcus, and Thermotoga species surveyed, produced, in most cases, near-maximal $\mathrm{H}_{2}$ yields with concomitant $\mathrm{CO}_{2}$ and acetate production, and little or no ethanol, formate, and lactate [24-40]. It is important to note that while some studies [29-31,34,35,39] report lower overall end-product yields, likely due to a large amount of carbon flux being directed towards biomass production under a given growth condition, $\mathrm{H}_{2}$ : ethanol ratios remain high. Cal. subterraneus subsp. tengcongensis, E. harbinense, and Clostridium species displayed mixed end-product fermentation patterns, with comparatively lower $\mathrm{H}_{2}, \mathrm{CO}_{2}$, and acetate yields, higher ethanol yields, and generally low formate and lactate yields [10,41-47]. Ta. pseudethanolicus produced the highest ethanol yields of the organisms surveyed with little concomitant $\mathrm{H}_{2}$, acetate, and lactate production, and 
Table 2 Summary of end-product yields, optimal growth temperatures, total molar reduction values of $\mathrm{H}_{2}+$ ethanol $\left(R V_{E P}\right)$, and growth conditions employed

\begin{tabular}{|c|c|c|c|c|c|c|c|c|c|c|}
\hline \multirow[t]{2}{*}{ Organism } & \multirow{2}{*}{$\begin{array}{l}\text { Growth } \\
\text { temp }\left({ }^{\circ} \mathrm{C}\right)\end{array}$} & \multicolumn{6}{|c|}{ End products (mol/mol hexose equivalent) } & \multirow[b]{2}{*}{$R V_{E P}$} & \multirow[t]{2}{*}{ Growth condition } & \multirow[t]{2}{*}{ Ref } \\
\hline & & $\mathrm{H}_{2}$ & $\mathrm{CO}_{2}$ & Acetate & Ethanol & Formate & Lactate & & & \\
\hline \multirow{4}{*}{$\begin{array}{l}\text { Ca. saccharolyticus } \\
\text { DSM } 8903\end{array}$} & \multirow[t]{4}{*}{70} & 4.0 & 1.8 & NR & ND & ND & ND & 4.0 & Cont., $1.1 \mathrm{~g} \mathrm{l}^{-1}$ glucose $\left(\mathrm{D}=0.09 \mathrm{~h}^{-1}\right)$ & {$[24]$} \\
\hline & & 3.6 & 1.5 & 1.6 & ND & ND & ND & 3.6 & Cont., $4.1 \mathrm{~g} \mathrm{l}^{-1}$ glucose $\left(\mathrm{D}=0.1 \mathrm{~h}^{-1}\right)$ & {$[24]$} \\
\hline & & 3.5 & NR & 2.1 & NR & NR & NR & 3.5 & Batch, $10 \mathrm{~g} \mathrm{I}^{-1}$ sucrose & {$[25]$} \\
\hline & & 2.5 & 1.4 & 1.4 & ND & ND & 0.1 & 2.5 & Batch, $10 \mathrm{~g} \mathrm{I}^{-1}$ glucose & {$[26]$} \\
\hline $\begin{array}{l}\text { Ca. bescii } \\
\text { DSM } 6725\end{array}$ & 75 & $\checkmark$ & $\checkmark$ & $\checkmark$ & NR & NR & $\checkmark$ & NA & & {$[27,28]$} \\
\hline \multirow{5}{*}{$\begin{array}{l}\text { P. furiosus } \\
\text { DSM } 3638\end{array}$} & \multirow[t]{5}{*}{90} & 3.8 & 1.9 & 1.5 & 0.1 & NR & NR & 4.0 & Cont, cellobiose $\left(\mathrm{D}=0.45 \mathrm{~h}^{-1}\right)$ & {$[29]^{\mathrm{A}}$} \\
\hline & & 3.5 & 1.0 & 1.4 & ND & NR & ND & 3.5 & Batch, $1.9 \mathrm{~g} \mathrm{l}^{-1}$, maltose & {$[30]^{\mathrm{A}}$} \\
\hline & & 2.9 & 1.9 & 0.8 & 0.1 & NR & ND & 3.1 & Batch, $2 \mathrm{~g} \mathrm{l}^{-1}$ maltose & {$[31]^{B}$} \\
\hline & & 2.8 & 0.9 & 1.2 & ND & NR & ND & 2.8 & Batch, $3.5 \mathrm{~g} \mathrm{l}^{-1}$, cellobiose & {$[30]^{\mathrm{A}}$} \\
\hline & & 2.6 & 1.4 & 1.0 & ND & NR & NR & 2.6 & Cont, maltose $\left(D=0.45 \mathrm{~h}^{-1}\right)$ & {$[29]^{A}$} \\
\hline $\begin{array}{l}\text { Th. kodakaraensis } \\
\text { KOD1 }\end{array}$ & 85 & 3.3 & 1.8 & 1.1 & NR & NR & NR & 3.3 & Cont, starch $\left(\mathrm{D}=0.2 \mathrm{~h}^{-1}\right)$ & {$[32]^{C}$} \\
\hline \multirow{5}{*}{$\begin{array}{l}\text { T. neapolitana } \\
\text { DSM } 4359\end{array}$} & \multirow[t]{5}{*}{$80-85$} & 3.8 & 2.0 & 1.8 & ND & NR & 0.1 & 3.8 & Batch, $2.5 \mathrm{~g} \mathrm{l}^{-1}$ glucose & [33] \\
\hline & & 3.2 & NR & 1.9 & $\mathrm{NR}$ & NR & NR & 3.2 & Batch ( $\mathrm{N}_{2}$ sparged), $7.0 \mathrm{gl}^{-1}$ glucose & {$[34]$} \\
\hline & & 2.4 & $\mathrm{NR}$ & 1.1 & NR & NR & 0.7 & 2.4 & Batch, $1.1 \mathrm{~g} \mathrm{I}^{-1}$ glucose & [35] \\
\hline & & 1.8 & NR & 1.0 & NR & NR & NR & 1.8 & Batch, $7.5 \mathrm{~g} \mathrm{I}^{-1}$ glucose & {$[40]$} \\
\hline & & 1.8 & NR & 1.5 & NR & NR & NR & 1.8 & Batch, $7.0 \mathrm{~g} \mathrm{l}^{-1}$ glucose & [34] \\
\hline $\begin{array}{l}\text { T. petrophila } \\
\text { RKU-1 }\end{array}$ & 80 & 3.7 & 0.4 & 1.8 & NR & NR & 0.3 & 3.7 & Batch, $1 \mathrm{~g} \mathrm{l}^{-1}$ glucose & {$[36]$} \\
\hline \multirow{3}{*}{$\begin{array}{l}\text { T. maritima } \\
\text { MSB8 }\end{array}$} & \multirow[t]{3}{*}{80} & 4.0 & 2.0 & 2.0 & NR & ND & NR & 4.0 & Batch, $2 \mathrm{~g} \mathrm{I}^{-1}$ glucose & {$[38]$} \\
\hline & & 2.2 & 1.1 & 1.0 & ND & NR & 0.3 & 2.2 & Batch, $3 \mathrm{~g} \mathrm{l}^{-1}$ glucose & {$[39]$} \\
\hline & & 1.7 & NR & 1.0 & NR & NR & NR & 1.7 & Batch, $7.5 \mathrm{~g} \mathrm{l}^{-1}$ glucose & {$[40]$} \\
\hline \multirow{3}{*}{$\begin{array}{l}\text { Cal. subterraneus } \\
\text { subsp. tengcongensis } \\
\text { MB4 }\end{array}$} & \multirow[t]{3}{*}{75} & 2.8 & NR & 1.4 & 0.6 & NR & ND & 4.0 & Cont, starch $\left(\mathrm{D}=0.27 \mathrm{~h}^{-1}\right)$ & [42] \\
\hline & & NR & NR & 2.0 & ND & NR & ND & NA & Cont $\left(\mathrm{N}_{2}\right.$ sparged), glucose $\left(\mathrm{D}=0.24 \mathrm{~h}^{-1}\right)$ & {$[42]$} \\
\hline & & 0.3 & 1.5 & 1.0 & 0.7 & NR & ND & 1.7 & Batch, $4 \mathrm{~g} \mathrm{l}^{-1}$ glucose & {$[41]$} \\
\hline $\begin{array}{l}\text { E. harbinense } \\
\text { YUAN-3 T }\end{array}$ & 35 & 2.8 & $\checkmark$ & 0.7 & 1.1 & ND & ND & 5.0 & Batch, $20 \mathrm{~g} \mathrm{I}^{-1}$ glucose & {$[43]$} \\
\hline \multirow{2}{*}{$\begin{array}{l}\text { C. cellulolyticum } \\
\text { H10 }\end{array}$} & \multirow[t]{2}{*}{37} & 1.6 & 1.0 & 0.8 & 0.3 & $\mathrm{ND}$ & NR & 2.2 & Batch, $5 \mathrm{~g} \mathrm{I}^{-1}$ cellulose & {$[44]$} \\
\hline & & 1.8 & 1.1 & 0.8 & 0.4 & ND & NR & 2,6 & Batch, $5 \mathrm{~g} \mathrm{l}^{-1}$ cellobiose & {$[44]$} \\
\hline \multirow{3}{*}{$\begin{array}{l}\text { C. phytofermentans } \\
\text { ISDg }\end{array}$} & \multirow[t]{3}{*}{$35-37$} & Major & Major & 0.6 & 1.4 & 0.1 & 0.3 & NA & Batch, $34 \mathrm{~g} \mathrm{I}^{-1}$ cellobiose & [45] \\
\hline & & 1.0 & 0.9 & 0.6 & 0.5 & 0.1 & NR & 2.0 & Batch, $5 \mathrm{~g} \mathrm{I}^{-1}$ cellulose & [44] \\
\hline & & 1.6 & 1.2 & 0.6 & 0.6 & ND & NR & 2.8 & Batch, $5 \mathrm{~g} \mathrm{l}^{-1}$ cellobiose & {$[44]$} \\
\hline \multirow{2}{*}{$\begin{array}{l}\text { C. thermocellum } \\
\text { ATCC } 27405\end{array}$} & \multirow[t]{2}{*}{60} & 0.8 & 1.1 & 0.7 & 0.8 & 0.3 & ND & 2.4 & Batch, $1.1 \mathrm{~g} \mathrm{l}^{-1}$ cellobiose & {$[10]$} \\
\hline & & 1.0 & 0.8 & 0.8 & 0.6 & 0.4 & 0.4 & 2.2 & Batch, $4.5 \mathrm{~g} \mathrm{l}^{-1}$ cellobiose & {$[46]$} \\
\hline \multirow{2}{*}{$\begin{array}{l}\text { C. thermocellum } \\
\text { DSM } 4150\end{array}$} & \multirow[t]{2}{*}{60} & 1.8 & 1.7 & 0.9 & 0.8 & ND & 0.1 & 3.4 & Batch, $2 \mathrm{~g} \mathrm{l}^{-1}$ glucose & {$[47]$} \\
\hline & & $\overline{0.6}$ & 1.8 & 0.3 & 1.4 & ND & 0.2 & 3.4 & Batch, $27 \mathrm{~g} \mathrm{I}^{-1}$ cellobiose & {$[47]$} \\
\hline Ta. pseudethanolicus & 65 & 0.1 & 2.0 & 0.1 & 1.8 & NR & 0.1 & 3.7 & Batch, $8 \mathrm{~g} \mathrm{l}^{-1}$ glucose & {$[50]$} \\
\hline & & $\overline{\mathrm{NR}}$ & NR & NR & 1.6 & NR & $<0.1$ & 3.2 & $1 \mathrm{gl}^{-1}$ xylose & {$[48]$} \\
\hline & & $\overline{N R}$ & NR & 0.4 & 1.0 & NR & $<0.1$ & 2.0 & Batch, $20 \mathrm{~g} \mathrm{l}^{-1}$ xylose & [49] \\
\hline & & $\overline{N R}$ & NR & 0.2 & 0.4 & NR & 1.1 & 0.8 & Batch, $20 \mathrm{~g} \mathrm{I}^{-1}$ glucose & [49] \\
\hline
\end{tabular}


Table 2 Summary of end-product yields, optimal growth temperatures, total molar reduction values of $\mathrm{H}_{2}+$ ethanol $\left(R V_{E P}\right)$, and growth conditions employed (Continued)

\begin{tabular}{|c|c|c|c|c|c|c|c|c|c|c|}
\hline $\begin{array}{l}\text { G. thermoglucosidasius } \\
\text { M10EXG }\end{array}$ & 60 & NR & NR & 0.6 & 0.4 & 1.0 & 0.9 & 0.8 & Batch, $10 \mathrm{~g} \mathrm{l}^{-1}$ glucose & {$[52]$} \\
\hline $\begin{array}{l}\text { B cereus } \\
\text { ATCC } 14579\end{array}$ & 35 & $N R$ & 0.1 & 0.2 & 0.2 & 0.3 & 1.1 & 0.4 & Batch, $3.6 \mathrm{~g} \mathrm{l}^{-1}$ glucose & {$[51]$} \\
\hline $\begin{array}{l}\mathrm{A} \sim 0.5 \text { mol alanine per } \mathrm{m} \\
{ }^{\mathrm{B}} \text { Produces } \mathrm{H}_{2}, \mathrm{CO}_{2} \text {, volati } \\
\mathrm{C}^{\mathrm{C}} \sim 0.5 \mathrm{~mol} \text { alanine per } \mathrm{m} \\
{ }^{\mathrm{D}} \text { Only G. thermoglucosida } \\
\text { comparisons instead. } \\
\text { Abbreviations: NR, not re } \\
\text { values indicated; Cont, } \mathrm{cc}\end{array}$ & $\begin{array}{l}\text { lol-he } \\
\text { le fatt } \\
\text { lol-he } \\
\text { suis s } \\
\text { porte }\end{array}$ & $\begin{array}{l}\text { ducec } \\
\text { and } \mathrm{N} \\
\text { ducec } \\
\text {-TS93 } \\
\text { det }\end{array}$ & $\begin{array}{l}\text { cell } \\
\text { on p } \\
\text { star } \\
\text { s bee }\end{array}$ & $\begin{array}{l}\text { iose a } \\
\text { tides } \mathrm{i} \\
\text { seque } \\
\text { not ar }\end{array}$ & $\begin{array}{l}\text { Itose } \\
\text { abser } \\
\text { out } \mathrm{n} \\
\text { le; } \mathrm{M}\end{array}$ & $\begin{array}{l}\text { carbc } \\
\text { prod } \\
\text { eport }\end{array}$ & is a & le. $S$ & $\begin{array}{l}\text { M10EXG was used for } \mathrm{e} \\
\text { out absolute values; } \checkmark \text {, re }\end{array}$ & no \\
\hline
\end{tabular}

no formate synthesis [48-50]. G. thermoglucosidasius and B. cereus produced the highest lactate and formate yields, moderate ethanol and acetate yields, and low $\mathrm{H}_{2}$ and $\mathrm{CO}_{2}$ yields $[51,52]$.

While reported yields vary considerably for each organisms, it is important to note that different growth conditions may influence end-product yields through regulation of gene and gene product expression $[42,53]$, and modulation of metabolic flux and intracellular metabolite levels $[54,55]$ that may act as allosteric regulators $[56,57]$. Variations in fermentation conditions including substrate availability/dilution rates [46,53-55,58-61], substrate composition [54,62-67], media composition [55], $\mathrm{pH}$ [68], gas partial pressures [34,42,69,70], growth phase [57], and accumulation of end-products $[47,62,69,71,72]$ have been shown to influence end-product yields. Hence, while genome content alone cannot be used to predict end-product yields with accuracy, it can reflect endproduct distribution profiles.

\section{Genome comparison of pyruvate metabolism and end- product synthesis pathways}

The assemblage of genes encoding proteins involved in pyruvate metabolism and end-product synthesis dictate, in part, how carbon and electron flux is distributed between the catabolic, anabolic, and energy producing pathways of the cell. The flow of carbon and electrons from PEP towards end-products may be separated into branch-points or nodes which include (i) the PEP/ oxaloacetate/pyruvate node, (ii) the pyruvate/lactate/ acetyl-CoA node, (iii) the acetyl-CoA/acetate/ethanol node, and the (iv) ferredoxin/NAD(P)H/ $\mathrm{H}_{2}$ node [73]. Several different enzymes may be involved in the conversion of intermediate metabolites within these nodes. These enzymes, and the presence of corresponding genes encoding these proteins in each of the organisms surveyed, are summarized in Figure 1. The oxidation of electron carriers (NADH and/or reduced ferredoxin) is required for maintaining glycolytic flux and leads to the ultimate production of reduced products (ethanol, lactate, and $\mathrm{H}_{2}$ ). Thus, distribution of carbon and electron flux among different pathways can influence levels of reduced electron carrier pools, which in turn can dictate end-product distribution patterns. Genome content can be used to resolve the relationship between carbon and electron flux with end-product distribution.

\section{Genes involved in pyruvate synthesis}

All organisms considered in this study utilize the Embden-Meyerhof-Parnas pathway for conversion of glucose to PEP with the following notable variations. Alignments of key residues of phosphofructokinase (PFK) according to Bapteste et al. [74,75], suggest that $P$. furiosus, Th. kodakaraensis, Cal. subterraneus subsp. tengcongensis, E. harbinense, G. thermoglucosidasius, and B. cereus encode an ATP-dependent PFK, while Thermotoga, Caldicellulosiruptor, Clostridium, and Thermoanaerobacter species encode both an ATP-dependent PFK, as well as a pyrophosphate $\left(\mathrm{PP}_{\mathrm{i}}\right)$-dependent PFK $[74,75]$ (Additional file 1). Furthermore, while bacteria catalyze the oxidation of glyceraldehyde-3-P to 3-phosphoglycerate (yielding NADH and ATP) with glyceraldehydes-3phosphate dehydrogenase (GAPDH) and phosphoglycerate kinase (PGK), archea (P. furiosus and Th. kodakaraensis) preferentially catalyze the same reaction via glyceraldehyde3-phosphate ferredoxin oxidoreductase (GAPFOR). This enzyme reduces ferredoxin $(\mathrm{Fd})$ rather than $\mathrm{NAD}^{+}$and does not produce ATP [76].

In contrast to the generally conserved gene content required for the production of PEP, a number of enzymes may catalyze the conversion of PEP to pyruvate [73] (Figure 1; Table 3). PEP can be directly converted into pyruvate via an ATP-dependent pyruvate kinase (PPK), or via an AMP-dependent pyruvate phosphate dikinase (PPDK). All strains considered in this review encode both $p p k$ and $p p d k$, with the exception of $C$. thermocellum strains, which do not encode a ppk, and E. harbinense, $G$. thermoglucosidasius, and B. cereus, which do not encode $p p d k$. Given that the formation of ATP from ADP and $\mathrm{P}_{\mathrm{i}}$ is more thermodynamically favorable than from AMP and $\mathrm{PP}_{\mathrm{i}}\left(\Delta \mathrm{G}^{\circ}=31.7\right.$ vs. $\left.41.7 \mathrm{~kJ} \mathrm{~mol}^{-1}\right)$, production of pyruvate via PPK is more favorable than via PPDK [21].

Flux balance analysis integrated with RNAseq data suggests higher carbon and electron flux in $C$. 
A- Ca. saccharolyticus DSM 8903

B- Ca. bescii DSM 6725

C- P. furiosus DSM 3638

D- Th. kodakaraensis KOD1

E- T. neapolitana DSM 4359

F- T. petrophila $\mathrm{RKU}-1$

G- $T$. maritima $\mathrm{MSB} 8$

$\mathrm{H}-$ Cal. subterraneus MB4

I- $E$. harbinense YUAN-3T

$\mathrm{J}-$ C. cellulolyticum $\mathrm{H} 10$

$\mathrm{K}-$ C. phytofermentans ISDg

L- C. thermocellum ATCC 27405

M- C. thermocellum DSM 4150

N- Ta. pseudethanolicus ATCC 33223

O- G. thermoglucosidsius C56-YS93

P- B. cereus ATCC 14579
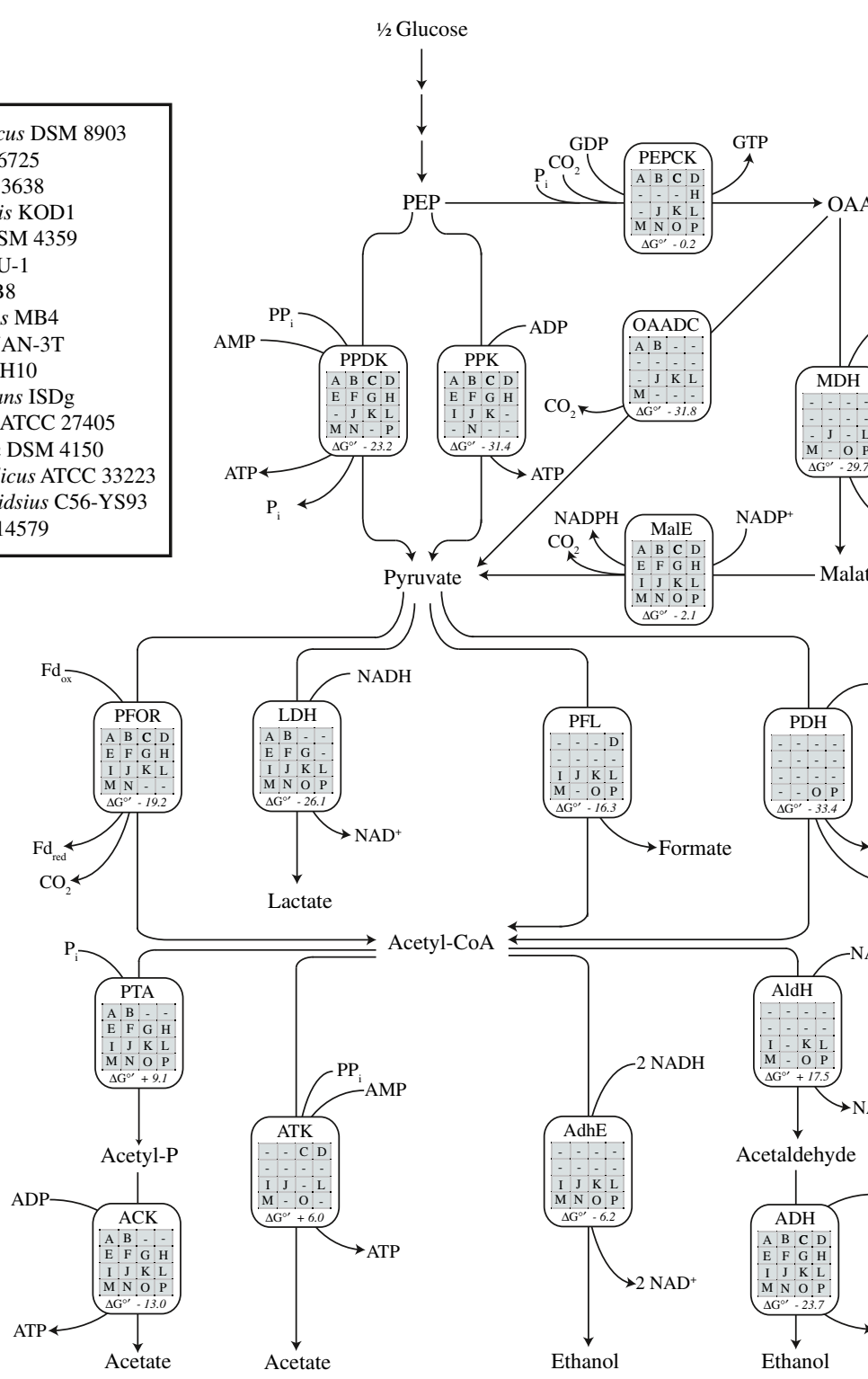

Acetaldehyde
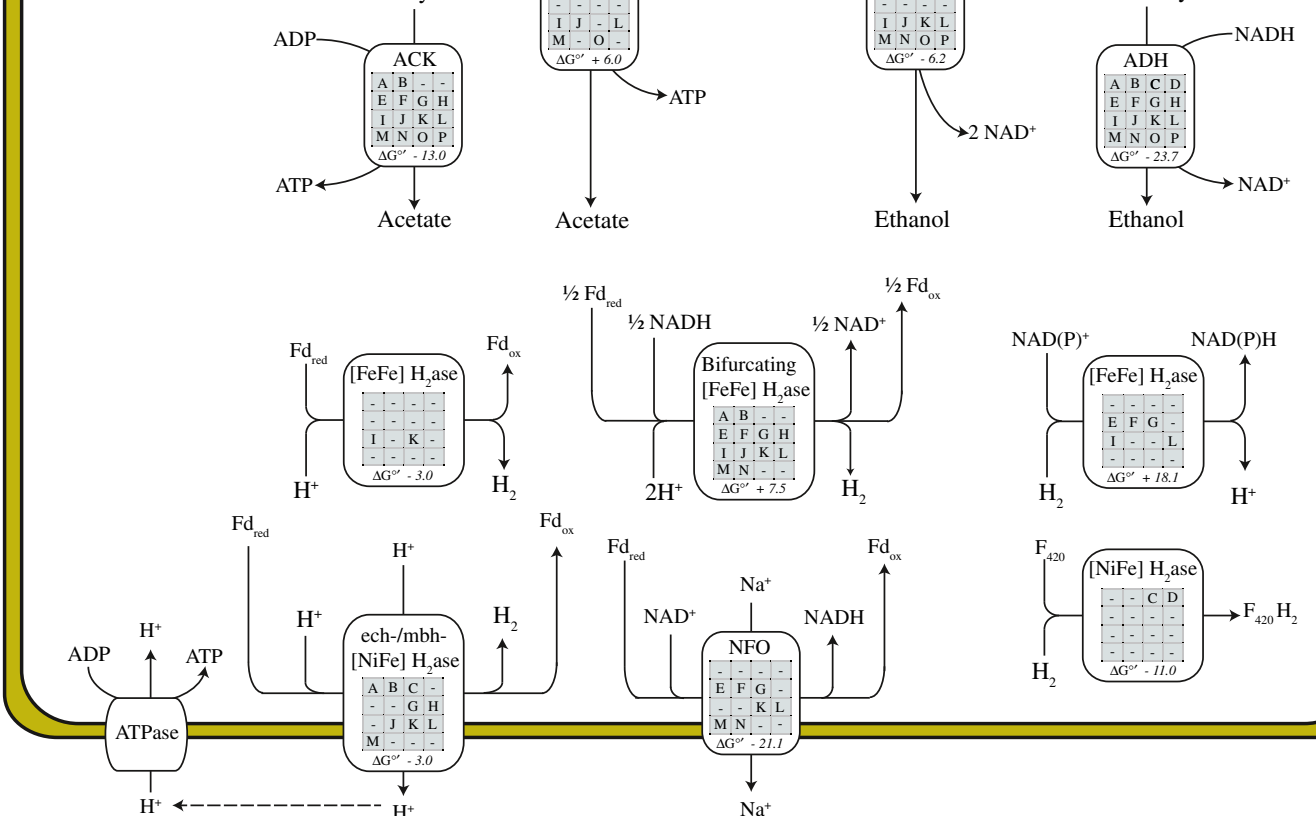

$\mathrm{Fd}_{\text {red }}$
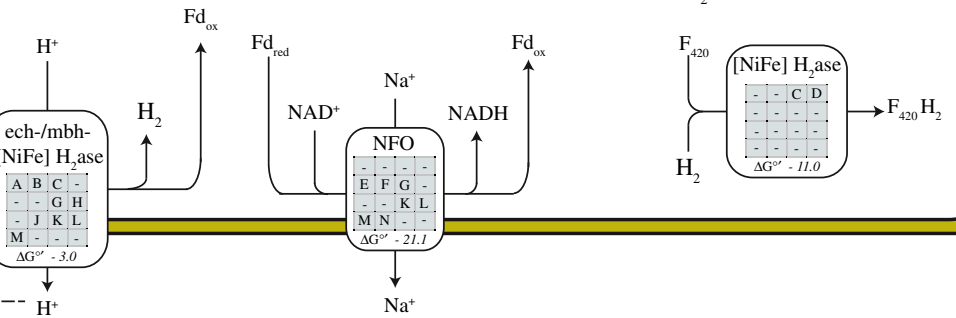

Figure 1 (See legend on next page.) 
(See figure on previous page.)

Figure 1 Comparison of putative gene products involved in pyruvate metabolism and end-product synthesis among select hydrogen and ethanol-producing species. Presence of putative gene products are indicated in matrix with respective letters corresponding to selected organism (see legend). Numbers indicate standard free energies of reaction $\left(\Delta G^{\circ}\right)$ corresponding to a particular enzyme. Abbreviations: PEPCK, phosphoenolpyruvate carboxykinase; OAADC, oxaloacetate decarboxylase; MDH, malate dehydrogenase; MalE, malic enzyme; PPK, pyruvate kinase; PPDK, pyruvate phosphate dikinase; LDH, lactate dehydrogenase; PFL, pyruvate formate lyase; PFOR, pyruvate:ferredoxin oxidoreductase; PDH, pyruvate dehydrogenase; ADH, alcohol dehydrogenase; ALDH, acetaldehyde dehydrogenase; AdhE, bifinctional acetaldehyde/alcohol dehydrogenase; ACK, acetate kinase; PTA, phosphotransacetylase; NFO, NADH:Fd oxidoreductase.

Table 3 Genes encoding proteins involved in interconversion of phosphenolpyruvate and pyruvate

\begin{tabular}{|c|c|c|c|c|c|c|c|}
\hline \multirow[t]{2}{*}{ Organism } & \multicolumn{7}{|c|}{ Gene } \\
\hline & eno & ppk & ppdk & pepck & oaadc & $m d h$ & MalE \\
\hline $\begin{array}{l}\text { Standard free energy } \\
\left(\Delta G^{\circ}\right)\end{array}$ & ND & -31.4 & -23.2 & -0.2 & -31.8 & -29.7 & -2.1 \\
\hline $\begin{array}{l}\text { Ca. saccharolyticus } \\
\text { DSM } 8903\end{array}$ & Athe_1403 & Athe_1266 & Athe_1409 & Athe_0393 & Athe_1316-1319 & & Athe_1062 \\
\hline $\begin{array}{l}\text { Ca. bescii } \\
\text { DSM } 6725\end{array}$ & Csac_1950 & Csac_1831 & Csac_1955 & Csac_0274 & Csac_2482-2485 & & Csac_2059 \\
\hline \multirow{2}{*}{$\begin{array}{l}\text { P. furiosus } \\
\text { DSM } 3638\end{array}$} & PF0215 & PF1188 & PF0043 & PF0289 & & & PF1026 \\
\hline & PF1641 & & & & & & \\
\hline \multirow{2}{*}{$\begin{array}{l}\text { Th. kodakaraensis } \\
\text { KOD1 }\end{array}$} & TK1497 & TK0511 & TK0200 & TK1405 & & & TK1963 \\
\hline & TK2106 & & TK1292 & & & & \\
\hline $\begin{array}{l}\text { T. neapolitana } \\
\text { DSM } 4359\end{array}$ & CTN_1698 & CTN_0477 & CTN_0413 & & & & CTN_0126 \\
\hline $\begin{array}{l}\text { T. petrophila } \\
\text { RKU-1 }\end{array}$ & Tpet_0050 & Tpet_0716 & Tpet_0652 & & & & Tpet_0379 \\
\hline $\begin{array}{l}\text { T. maritima } \\
\text { MSB8 } \\
\end{array}$ & TM0877 & TM0208 & TM0272 & & & & TM0542 \\
\hline \multirow{2}{*}{$\begin{array}{l}\text { Cal. subterraneus } \\
\text { subsp. tengcongensis } \\
\mathrm{MB}^{\mathrm{A}}\end{array}$} & TTE1759 & TTE1815 & TTE0164 & TTE1783 & & & TTE2332 \\
\hline & & & TTE0981 & & & & \\
\hline $\begin{array}{l}\text { E. harbinense } \\
\text { YUAN-3 T }\end{array}$ & Ethha_2662 & Ethha_0305 & & & & & Ethha_0739 \\
\hline $\begin{array}{l}\text { C. cellulolyticum } \\
\mathrm{H} 10\end{array}$ & Ccel_2254 & Ccel_2569 & Ccel_2388 & Ccel_0212 & Ccel_1736-1738 & Ccel_0137 & Ccel_0138 \\
\hline \multirow{2}{*}{$\begin{array}{l}\text { C. phytofermentans } \\
\text { ISDg }\end{array}$} & Cphy_3001 & Cphy_0741 & Cphy_0651 & Cphy_3853 & Cphy_2433-2434 & & Cphy_0409 \\
\hline & & Cphy_2900 & & & & & \\
\hline \multirow{2}{*}{$\begin{array}{l}\text { C. thermocellum } \\
\text { ATCC } 27405\end{array}$} & Cthe_0143 & & Cthe_1253 & Cthe_2874 & Cthe_0699-0701 & Cthe_0345 & Cthe_0344 \\
\hline & & & Cthe_1308 & & & & \\
\hline \multirow{2}{*}{$\begin{array}{l}\text { C. thermocellum } \\
\text { DSM } 4150\end{array}$} & & & CtherDRAFT_1661 & CtherDRAFT_1742 & CtherDRAFT_ & Yes $^{\mathrm{A}}$ & Yes $^{A}$ \\
\hline & & & $\overline{\text { CtherDRAFT_1896 }}$ & & & & \\
\hline \multirow{2}{*}{$\begin{array}{l}\text { Ta. pseudethanolicus } \\
\text { 39E }\end{array}$} & Teth39_0735 & Teth39_0684 & Teth39_1358 & Teth39_0711 & & & Teth39_0337 \\
\hline & & & Teth39_2098 & & & & \\
\hline \multirow{2}{*}{$\begin{array}{l}\text { G. thermoglucosidasius } \\
\text { C56-YS93 }\end{array}$} & Geoth_0446 & Geoth_0898 & & Geoth_0811 & & Geoth_0904 & Geoth_1713 \\
\hline & & & & & & Geoth_3508 & Geoth_2444 \\
\hline \multirow{3}{*}{$\begin{array}{l}\text { B.cereus } \\
\text { ATCC } 14579\end{array}$} & BC5135 & BC3323 & BC3087 & BC4762 & & BC4592 & BC0580 NAD) \\
\hline & & BC4599 & & & & BC2959 & BC1741 (NAD) \\
\hline & & & & & & & BC4604 (NADP \\
\hline
\end{tabular}

${ }^{\mathrm{A}}$ Genes have been verified by PCR amplification (unpublished).

Abbreviations: eno, enolase; ppk, pyruvate kinase; ppdk, pyruvate phosphate dikinase; pepck, phosphoenolpyruvate carboxykinase; oaadc, oxaloacetate decarboxylase; $m d h$, malate dehydrogenase; malE, malic enzyme. 
thermocellum ATCC 27405 is directed through enzymes capable of direct, rather than indirect, conversion of PEP to pyruvate [77]. However, C. cellulolyticum mutation studies suggests that a portion of PEP can also be converted to pyruvate via the "malate shunt" [78]. This PPK/PPDK bypass system utilizes either (i) phosphoenolpyruvate carboxykinase (PEPCK), malate dehydrogenase $(\mathrm{MDH})$, and malic enzyme (MalE), or (ii) PEPCK and oxaloacetate decarboxylase (OAADC), for the interconversion of PEP and pyruvate (Figure 1). While PEPCK provides a pathway for energy conservation via ATP (or GTP) production, $\mathrm{MDH}$ and MalE permit transhydrogenation from $\mathrm{NADH}$ to $\mathrm{NADP}^{+}$[71], generating additional reducing equivalents required for biosynthesis. $G$. thermoglucosidasius, B. cereus, $C$. thermocellum (ATCC 27405), and C. cellulolyticum contain pepck, mdh and malE suggesting that they are capable of transhydrogenation using these proteins. Although the draft genome of

thermocellum DSM 4150 does not include genes encoding $\mathrm{MDH}$ and MalE, we have verified their presence via PCR amplification (unpublished results). Deletion of $m d h$ in C. cellulolyticum resulted in significant increases in lactate, and to a lesser extent ethanol yields, and reduced acetate production when grown on cellulose demonstrating carbon and electron flux through $\mathrm{MDH}$ in wild type strains [78]. It seems evident that in the absence of $\mathrm{MDH}$, transhydrogenation was reduced, and thus the resulting increase in NADH:NADPH ratios promote lactate and ethanol production, while decreasing NADPH levels for biosynthesis.

A number of organisms analyzed encode pepck and oaadc (Ca. bescii, Ca. saccharolyticus, C. cellulolyticum, C. phytofermentans, and C. thermocellum), also allowing for indirect conversion of PEP to pyruvate via an oxaloacetate intermediate. While the redirection of carbon and electron flux through this pathway likely has little effect on product yields, synthesis of GTP, versus ATP, may promote transcription and protein synthesis. Finally, Cal. subterraneus, E. harbinense, P. furiosus, Th. kodakaraensis, Ta. pseudethanolicus, and Thermotoga species do not encode all of the proteins required for a "malate shunt" and consequentially the catalysis of PEP to pyruvate must be achieved via PPK and/or PPDK.

\section{Genes involved in pyruvate catabolism}

The pyruvate/lactate/acetyl-CoA node plays an important role in regulating carbon flux and electron distribution and dramatically affects end-product distribution. The NADH-dependent reduction of pyruvate to lactate via fructose-1,6-bisphosphate activated lactate dehydrogenase (LDH) [56] diverts reducing equivalents away from biofuels such as $\mathrm{H}_{2}$ and ethanol. Alternatively, the oxidative decarboxylation of pyruvate to acetyl-CoA via pyruvate dehydrogenase ( $p d h)$ or pyruvate:ferreodoxin oxidoreductase (pfor) generate NADH and reduced Fd, respectively. These reducing equivalents may then be oxidized during the production of $\mathrm{H}_{2}$ or ethanol (Figure 1). Pyruvate may also be catabolised to acetyl-CoA via pyruvate:formate lyase $(p f l)$ yielding formate in the process. In some enterobacteria, formate is further oxidized to $\mathrm{CO}_{2}$, releasing $\mathrm{H}_{2}$, through the action of a multisubunit formate hydrogen lyase (FHL) complex [79]. However, pfl was not encoded in any of the organisms analysed.

With the exception of Cal. subterraneus subsp. tengcongensis, P. furiosus, and Th. kodakaraensis, ldh genes were identified in all organisms studied (Table 4). Surprisingly, while the production of lactate from pyruvate is highly favorable thermodynamically $\left(\Delta \mathrm{G}^{\circ}=-26.1 \mathrm{~kJ} \mathrm{~mol}^{-1-}\right)$, only $B$. cereus, G. thermoglucosidasius, and, under some conditions, Ta. pseudethanolicus and T. neapolitana produce high yields of lactate $\left(>0.5 \mathrm{~mol}\right.$ mol-glucose $\left.{ }^{-1}\right)$. In all other organisms surveyed lactate production was either a minor end-product, not detected, or not reported under the reported growth conditions (Table 2). This suggests that the presence of $l d h$ cannot be used to predict lactate production.

LDH is, in fact, allosterically activated by fructose-1, 6-bisphosphate in C. thermocellum ATCC 27405, Ca. saccharolyticus, and Thermoanaerobacter brockii $[56,57,62,80]$. While enzyme assays reveal high LDH activity in $C$. thermocellum [10,72], most studies report only trace amounts of lactate. Islam et al. [46], however, demonstrated that lactate production was triggered in stationary-phase batch cultures only under excess cellobiose conditions. In Thermoanaerobacter brockii, Ben-Bassat et al. reported elevated lactate production as a consequence of accumulated intracellular fructose-1,6-bisphosphate (FDP) when cultures were grown on glucose compared to starch [62]. Finally, Willquist and van Niel [57] reported that LDH in Ca. saccharolyticus was activated by FDP and ATP, and inhibited by $\mathrm{NAD}^{+}$and $\mathrm{PP}_{\mathrm{i}}$. An increase in fructose-1,6-bisphosphate, NADH:NAD ${ }^{+}$ratios, and ATP:PP ${ }_{\mathrm{i}}$ ratios was observed during the transition from exponential to stationary phase in $\mathrm{Ca}$. saccharolyticus cultures, and was accordingly accompanied by lactate production [57].

All organisms analyzed encode either pdh or pfor, but not both (Table 4). While G. thermoglucosidasius and $B$. cereus encode $p d h$, all other organisms analyzed encode pfor. Although Caldicellulosiruptor, Clostridia, and Thermoanaerobacter species studied appear to encode a putative $p d h$, there has been no enzymatic evidence to support the presence of PDH in these species. Thus far, only PFOR activity has been verified in C. cellulolyticum $[58,60]$ and $C$. thermocellum [10,72]. The putative E1, E2, and E3 subunits of the pdh complex (Csac_08740872) in Ca. saccharolyticus were designated simply as a keto-acid dehydrogenase by van de Werken et al. 
Table 4 Genes encoding proteins directly involved in pyruvate catabolism

\begin{tabular}{|c|c|c|c|c|}
\hline \multirow[t]{2}{*}{ Organism } & \multicolumn{4}{|c|}{ Gene } \\
\hline & Idh & $p d h$ & pfor & pfl \\
\hline Standard free energy $\left(\mathrm{G}^{\circ}\right)$ & -26.1 & -33.4 & -19.2 & -16.3 \\
\hline \multirow[t]{2}{*}{ Ca. saccharolyticus DSM 8903} & Csac_1027 & & Csac_1458-1461 & \\
\hline & & & Csac_2248-2249 & \\
\hline \multirow[t]{2}{*}{ Ca. bescii DSM 6725} & Athe_1918 & & Athe_0874-0877 & \\
\hline & & & Athe_1708-1709 & \\
\hline P. furiosus DSM 3638 & & & PF0965-PF0967, PF0971 & \\
\hline Th. kodakaraensis KOD1 & & & TK1978, TK1982-1984 & TK0289 \\
\hline T. neapolitana DSM 4359 & CTN_0802 & & CTN_0680-CTN_0683 & \\
\hline T. petrophila RKU-1 & Tpet_0930 & & Tpet_0905-Tpet_0908 & \\
\hline T. maritima MSB8 & TM1867 & & TM0015-TM0018 & \\
\hline \multirow[t]{2}{*}{ Cal. subterraneus subsp. tengcongensis MB4 } & & & TTE0445 & \\
\hline & & & TTE0960 & \\
\hline \multirow[t]{2}{*}{ E. harbinense YUAN-3 T } & Ethha_1350 & & Ethha_0231-0234 & Ethha_1657 \\
\hline & Ethha_2705 & & & \\
\hline \multirow[t]{2}{*}{ C. cellulolyticum $\mathrm{H} 10$} & Ccel_2485 & & Ccel_0016 & Ccel_2224 \\
\hline & & & Ccel_1164 & Ccel_2582 \\
\hline \multirow[t]{3}{*}{ C. phytofermentans ISDg } & Cphy_1117 Cphy_1232 & & Cphy_0603 Cphy_3558 & Cphy_1174 \\
\hline & & & & Cphy_1417 \\
\hline & & & & Cphy_2823 \\
\hline \multirow[t]{3}{*}{ C. thermocellum ATCC 27405} & Cthe_1053 & & Cthe_2390-2393 & Cthe_0505 \\
\hline & & & Cthe_2794-2797 & \\
\hline & & & Cthe_3120 & \\
\hline \multirow[t]{3}{*}{ C. thermocellum DSM 4150} & CtherDRAFT_2943 & & CtherDRAFT_0414-0417 & CtherDRAFT_2234 \\
\hline & & & $\overline{\text { CtherDRAFT_1182-1185 }}$ & \\
\hline & & & CtherDRAFT_1311 & \\
\hline Ta. pseudethanolicus 39E & Teth39_1997 & & $\begin{array}{l}\text { Teth39_0289 } \\
\text { Teth39_1842 }\end{array}$ & \\
\hline \multirow[t]{5}{*}{ G. thermoglucosidasius C56-YS93 } & Geoth_3351 & Geoth_0237-0239 & & Geoth_3895 \\
\hline & & $\overline{\text { Geoth_1595-1597 }}$ & & \\
\hline & & $\overline{\text { Geoth_2366-2368 }}$ & & \\
\hline & & $\overline{\text { Geoth_2479-2480 }}$ & & \\
\hline & & $\overline{\text { Geoth_2860-2863 }}$ & & \\
\hline \multirow[t]{3}{*}{ B.cereus ATCC 14579} & BC1924 & BC3970-3973 & & $\mathrm{BC} 0491$ \\
\hline & BC4870 & & & \\
\hline & BC4996 & & & \\
\hline
\end{tabular}

Abbreviations: Idh, lactate dehydrogenase; $p d h$, pyruvate dehydrogenase; pfor, pyruvate:ferredoxin oxidoreductase; pfl, pyruvate formate lyase.

[81]. Similarly, while genes encoding a putative $p d h$ (Teth_0790-0793) are present in Ta. pseudethanolicus, genomic context strongly supports that this putative $p d h$ is part of an acetoin dehydrogenase complex, despite the absence of reported acetoin production. In Clostridia species, putative $p d h$ 's (Cthe_3449-3450, Cthe_1543) may actually encode 2-oxo acid dehydrogenase complexes, which share a common structure and homology to pyruvate dehydrogenase. These include 2-oxoglutarate dehydrogenase, branched-chain alpha-keto acid dehydrogenase, acetoin dehydrogenase complex, and the glycine cleavage complex. All organisms that encode a pfor also encode a Fddependent hydrogenase $\left(\mathrm{H}_{2}\right.$ ase), bifurcating $\mathrm{H}_{2}$ ase, and/or a NADH:Fd oxidoreductase (NFO), and are thus capable of reoxidizing reduced Fd produced by PFOR. Conversely, G. thermoglucosidasius and B. cereus, which encode $p d h$ but not pfor, do not encode enzymes capable of reoxidizing reduced $\mathrm{Fd}$, and thus do not produce $\mathrm{H}_{2}$. While the presence of PDH allows for additional NADH production that could be used for ethanol production, 
G. thermoglucosidasius and B. cereus end-product profiles suggest that this NADH is preferentially rexodized through lactate production rather than ethanol production. Pyruvate decarboxylase, a homotetrameric enzyme that catalyzes the decarboxylation of pyruvate to acetaldehyde was not encoded by any of the species considered in this study.

Given the requirement of reduced electron carriers for the production of ethanol $/ \mathrm{H}_{2}$, the oxidative decarboxylation of pyruvate via PDH/PFOR is favorable over PFL for the production of these biofuels. Genome analyses revealed that a number of organisms, including $P$. furiosus, Ta. pseudethanolicus, Cal. subterraneus subsp. tencongensis, and all Caldicellulosiruptor and Thermotoga species considered, did not encode PFL. In each of these species, the production of formate has neither been detected nor reported. Unfortunately, many studies do not report formate production, despite the presence of PFL. This may be a consequence of the quantification methods used for volatile fatty acid detection. When formate is not produced, the total oxidation value of $2 \mathrm{CO}_{2}$ per mole glucose $(+4)$, must be balanced with the production of $\mathrm{H}_{2}$ and/or ethanol. Thus, the "total molar reduction values of reduced end-products $\left(\mathrm{H}_{2}+\right.$ ethanol)", termed $\bar{R} V_{E P}$ should be $-\overline{4}$, providing that all carbon and electron flux is directed towards end-product formation and not biosynthesis. Indeed, $R V_{E P}$ 's were usually greater than 3.5 in organisms that do not encode pfl (T. maritima, Ca. saccharolyticus), and below 3.5 in those that do encode pfl (C. phytofermentans, C. thermocellum, G. thermoglucosidasius, and B. cereus; Table 2). In some studies, $R V_{E P}$ 's were low due to a large amount of carbon and electron flux directed towards biosynthesis. In $G$. thermoglucosidasius and $B$. cereus $R V_{E P}$ 's of $\mathrm{H}_{2}$ plus ethanol ranged from 0.4 to 0.8 due to higher reported formate yields. The large differences in formate yields between organisms that encode pfl may be due to regulation of pfl. In Escherichia coli $[82,83]$ and Streptococcus bovis [84,85], pfl expression has been shown to be negatively regulated by AdhE. Thus presence of $p f l$ alone is not a good indicator of formate yields.

\section{Genes involved in acetyl-CoA catabolism, acetate production, and ethanol production}

The acetyl-CoA/acetate/ethanol node represents the third major branch-point that dictates how carbon and electrons flow towards end-products (Figure 1). AcetylCoA may be converted to acetate, with the concomitant production of ATP, either indirectly through an acetyl phosphate intermediate using phosphotransacetylase (pta) and acetate kinase (ack), or directly via acetate thiokinase (atk). Although both reactions produce ATP, the former uses ADP and $P_{i}$ whereas the latter uses AMP and inorganic $\mathrm{PP}_{\mathrm{i}}$ as substrates for ATP synthesis.
As a result, acetate production via pta and ack is more thermodynamically favorable than via atk $\left(\triangle \mathrm{G}^{\circ}=-3.9\right.$ vs. $+6.0 \mathrm{~kJ} / \mathrm{mol}$, respectively) which is typically used for acetate assimilation. Of the organisms surveyed, E. harbinense, G. thermodenitrificans, C. cellulolyticum, both C. thermocellum strains, and G. thermoglucosidasius contain all three genes capable of converting pyruvate to acetate (Table 5). Conversely, Cal. subterraneus subsp. tengcongensis, Thermotoga and Caldicellulosiruptor species, C. phytofermentans, Ta. pseudethanolicus, and B. cereus encode only pta and ack, whereas $P$. furiosus and Th. kodakaraensis encode only atk.

Alternatively, acetyl-CoA may be converted into ethanol, during which $2 \mathrm{NADH}$ (or NADPH) are oxidized, either directly via a fused acetaldehyde/alcohol dehydrogenase encoded by $a d h E$, which has been proposed to be the key enzyme responsible for ethanol production $[86,87]$, or indirectly through an acetaldehyde intermediate via acetaldehyde dehydrogenase $($ ald $H)$ and alcohol dehydrogenase $(a d h)$. While all organisms surveyed encoded multiple class IV Fe-containing ADHs (Table 5), the functions of these ADHs may vary with respect to substrate specificity (aldehyde length and substitution), coenzyme specificity (NADH vs. NADPH), and the catalytic directionality favored (ethanol formation vs. consumption) [10,57-59,72,88-91]. Although there are reports of in silico determinations of substrate and cofactor specificity amongst ADHs, in our experience such resolutions are problematic [92,93]. Often times, the gene neighborhoods of identified ADHs were suggestive that the physiological role of many enzymes was not ethanol production. This is evident in Ca. saccharolyticus, which does not produce ethanol despite reported NADPH-dependent ADH activity [57].

P. furiosus, Th. kodakaraensis, and all Thermotoga and Caldicellulosiruptor species do not encode $a d h E$ or ald $H$, and therefore produce negligible or no ethanol. Given the absence of ethanol producing pathways in these species, reducing equivalents are disposed of through $\mathrm{H}_{2}$ production via $\mathrm{H}_{2}$ ases and/or lactate production via LDH. Surprisingly, while Cal. subterraneus subsp. tengcongensis also does not appear to encode aldH or adhE, NADPH-dependent AldH and both $\mathrm{NADH}$ and $\mathrm{NADPH}$-dependent $\mathrm{ADH}$ activities, as well as ethanol production, have been reported by Soboh et al. [42]. Similarly, Caldicellulosiruptor obsidiansis, which does not encode aldH or adhE, does produce trace levels of ethanol, suggesting that the various encoded ADHs may have broad substrate specificities [94]. Although $C$. cellulolyticum and Ta. pseudethanolicus do not encode ald $H$, they do encode $a d h E$, and thus are capable of ethanol production. Of the organisms surveyed, only $G$. thermoglucosidasius and C. cellulolyticum encoded ald $H$ and adh but no adhE, and produced 
Table 5 Genes encoding proteins involved in end-product synthesis from acetyl-CoA

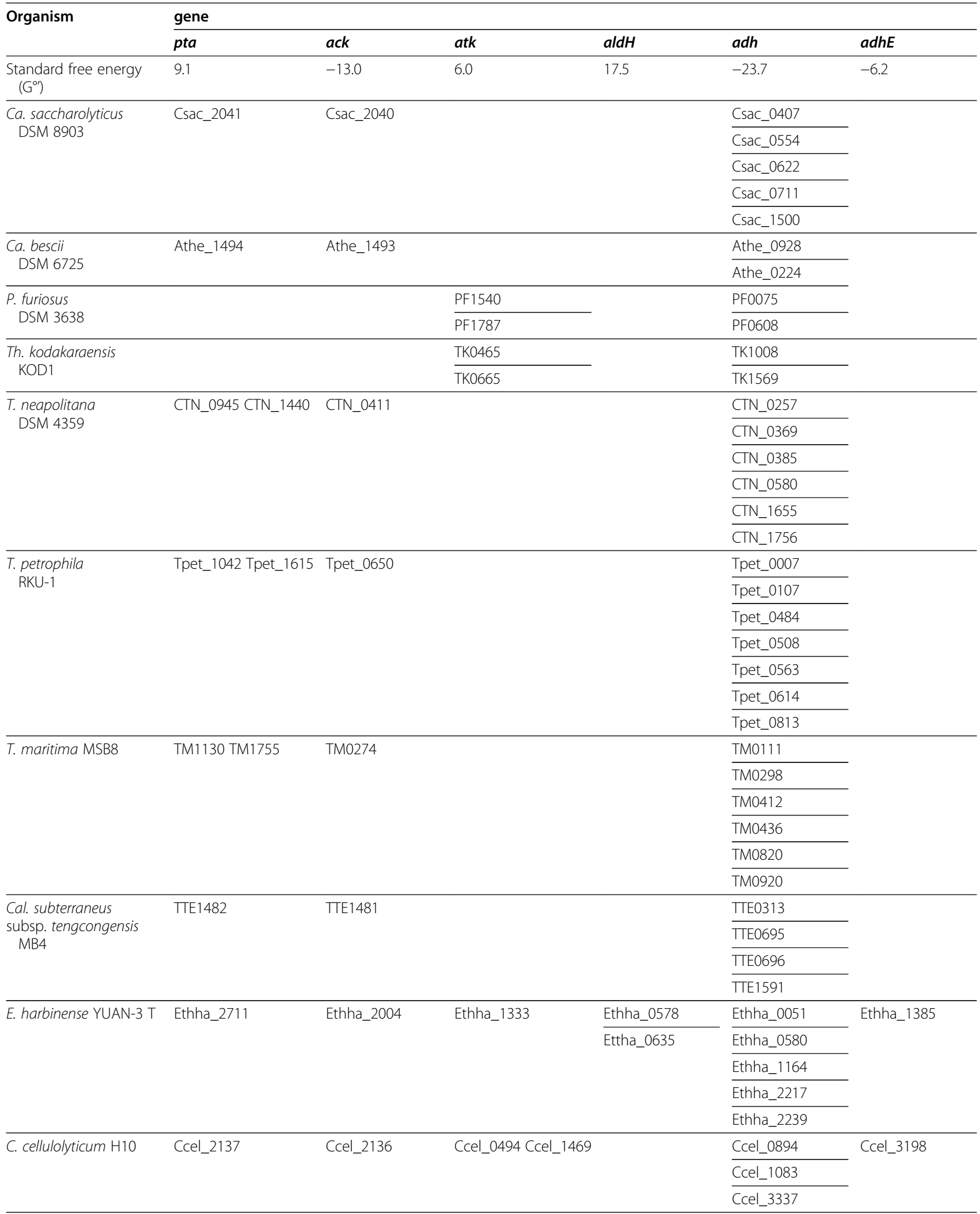


Table 5 Genes encoding proteins involved in end-product synthesis from acetyl-CoA (Continued)

\begin{tabular}{|c|c|c|c|c|c|c|}
\hline \multirow[t]{7}{*}{ C. phytofermentans ISDg } & \multirow[t]{7}{*}{ Cphy_1326 } & \multicolumn{2}{|l|}{ Cphy_132 } & \multirow{2}{*}{$\begin{array}{l}\text { Cphy_0958 } \\
\text { Cphy_1178 } \\
\end{array}$} & \multirow{2}{*}{$\begin{array}{l}\text { Cphy_1029 } \\
\text { Cphy_1421 }\end{array}$} & \multirow[t]{7}{*}{ Cphy_3925 } \\
\hline & & & & & & \\
\hline & & & & Cphy_1416 & Cphy_2463 & \\
\hline & & & & Cphy_1428 & Cphy_2463 & \\
\hline & & & & Cphy_2418 & & \\
\hline & & & & Cphy_2642 & & \\
\hline & & & & Cphy_3041 & & \\
\hline \multirow{3}{*}{$\begin{array}{l}\text { C. thermocellum } \\
\text { ATCC } 27405\end{array}$} & \multirow[t]{3}{*}{ Cthe_1029 } & \multirow[t]{3}{*}{ Cthe_1028 } & \multirow[t]{3}{*}{ Cthe_0551 } & \multirow[t]{3}{*}{ Cthe_2238 } & Cthe_0101 & \multirow[t]{3}{*}{ Cthe_0423 } \\
\hline & & & & & Cthe_0394 & \\
\hline & & & & & Cthe_2579 & \\
\hline \multirow{3}{*}{$\begin{array}{l}\text { C. thermocellum } \\
\text { DSM } 4150\end{array}$} & \multirow[t]{3}{*}{ CtherDRAFT_2741 } & \multirow[t]{3}{*}{ CtherDRAFT_2742 } & \multirow[t]{3}{*}{ CtherDRAFT_2349 } & \multirow[t]{3}{*}{ CtherDRAFT_1042 } & CtherDRAFT_0189 & \multirow[t]{3}{*}{ CtherDRAFT_1096 } \\
\hline & & & & & CtherDRAFT_0616 & \\
\hline & & & & & CtherDRAFT_2833 & \\
\hline \multirow{3}{*}{$\begin{array}{l}\text { Ta. pseudethanolicus } \\
\text { 39E }\end{array}$} & \multirow[t]{3}{*}{ Teth39_1296 } & \multirow[t]{3}{*}{ Teth39_1295 } & & & Teth39_0220 & \multirow[t]{3}{*}{ Teth39_0206 } \\
\hline & & & & & Teth39_1597 & \\
\hline & & & & & Teth39_1979 & \\
\hline \multirow{3}{*}{$\begin{array}{l}\text { G. thermoglucosidasius } \\
\text { C56-YS93 }\end{array}$} & \multirow[t]{3}{*}{ Cthe_3862 } & \multirow[t]{3}{*}{ Geoth_0875 } & Geoth_0855 & Geoth_0268 & Geoth_1572 & \multirow[t]{3}{*}{ Geoth_3879 } \\
\hline & & & Geoth_0879 & Geoth_0652 & Geoth_1941 & \\
\hline & & & Geoth_2349 & Geoth_3494 & Geoth_0631 & \\
\hline \multirow[t]{3}{*}{ B. cereus ATCC 14579} & \multirow[t]{3}{*}{ BC5387 } & \multirow{3}{*}{\multicolumn{2}{|c|}{ BC4637 }} & BC2832 & BC0802 & \multirow[t]{3}{*}{ BC4365 } \\
\hline & & & & BC3555 & BC2529 & \\
\hline & & & & BC1285 & BC2220 & \\
\hline
\end{tabular}

Abbreviations: pta, phosphotransacetylase; ack, acetate kinase; atk, acetate thiokinase; aldH, acetaldehyde dehydrogenase; adh, alcohol dehydrogenase; adhE; bifunctional acetylaldehyde/alcohol dehydrogenase.

moderate amounts of ethanol $(\sim 0.4 \mathrm{~mol}$ per mol hexose). Conversely, a number of organisms (E. harbinense, $C$. phytofermentans, both C. thermocellum strains, G. thermoglucosidasius, and B. cereus) encoded aldH, adh, and $a d h E$, all of which produce varying ethanol yields.

\section{Hydrogenases}

In addition to disposal of reducing equivalents via alcohol and organic acid production, electrons generated during conversion of glucose to acetyl-CoA can be used to produce molecular hydrogen via a suite of [FeFe] and/or [NiFe] $\mathrm{H}_{2}$ ases. The incredible diversity of $\mathrm{H}_{2}$ ases has been extensively reviewed by Vignais et al. and Calusinska et al. [16,95,96]. $\mathrm{H}_{2}$ ases may be (i) monomeric or multimeric, (ii) can catalyze the reversible production of $\mathrm{H}_{2}$ using various electron donors, including reduced $\mathrm{Fd}$ and $\mathrm{NAD}(\mathrm{P}) \mathrm{H}$, or (iii) can act as sensory $\mathrm{H}_{2}$ ases capable of regulating gene expression [97]. While most $\mathrm{H}_{2}$ ases can reversibly shuttle electrons between electron carriers and $\mathrm{H}_{2}$, they are typically committed to either $\mathrm{H}_{2}$-uptake or evolution, depending on reaction thermodynamics and the requirements of the cell in vivo [95]. While Fd-dependent $\mathrm{H}_{2}$ production remains thermodynamically favorable at physiological concentrations $\left(\triangle \mathrm{G}^{\circ} \sim-3.0 \mathrm{~kJ} \mathrm{~mol}^{-1}\right)$, potential production of $\mathrm{H}_{2}$ from $\mathrm{NAD}(\mathrm{P}) \mathrm{H} \quad\left(\Delta^{\circ}{ }^{\circ}=+18.1 \mathrm{~kJ} \mathrm{~mol}^{-1}\right)$ becomes increasingly unfavorable with increasing hydrogen partial pressure [98]. Hence, Fd-dependent $\mathrm{H}_{2}$ ases are associated with $\mathrm{H}_{2}$ evolution, whereas NAD $(\mathrm{P}) \mathrm{H}$ dependent $\mathrm{H}_{2}$ ases are more likely to catalyze $\mathrm{H}_{2}$ uptake. Recent characterization of a heterotrimeric "bifurcating" $\mathrm{H}_{2}$ ase from Thermotoga maritma demonstrated that it can simultaneously oxidize reduced Fd and NADH to $\mathrm{H}_{2}\left(\Delta \mathrm{G}^{\circ} \sim+7.5 \mathrm{~kJ} \mathrm{~mol}^{-1}\right)$, which drives the endergonic production of $\mathrm{H}_{2}$ from NADH by coupling it to the exergonic oxidation of reduced Fd [99].

With the exception of G. thermoglucosidasius and $B$. cereus, which did not contain putative $\mathrm{H}_{2}$ ase genes, the genomes of all of the organisms surveyed encode multiple $\mathrm{H}_{2}$ ases. These $\mathrm{H}_{2}$ ases were classified based on i) the phylogenetic relationship of $\mathrm{H}_{2}$ ase large subunits (Additional file 2 and Additional file 3), according to Calusinska et al. [16], ii) $\mathrm{H}_{2}$ ase modular structure, and iii) subunit composition, based on gene neighbourhoods. Encoded [NiFe] $\mathrm{H}_{2}$ ases fell into 3 major subgroups including: (i) Fd-dependent, $\mathrm{H}_{2}$-evolving, membranebound $\mathrm{H}_{2}$ ases $(\mathrm{Mbh})$ and/or energy conserving [NiFe] $\mathrm{H}_{2}$ ases (Ech) capable of generating sodium/proton motive force (Group 4) [42], (ii) Soluble cofactordependent $\left(\mathrm{F}_{420}\right.$ or $\left.\mathrm{NAD}(\mathrm{P}) \mathrm{H}\right)$, bidirectional, cytoplasmic, heteromultimeric $\mathrm{H}_{2}$ ases (Group 3), and (iii) $\mathrm{H}_{2}$-uptake, membrane bound $\mathrm{H}_{2}$ ases (Group 1) [96] (Additional 
Table 6 Genes encoding putative hydrogenases, sensory hydrogenases, and NADH:Fd oxidoreductases using ferredoxin, coenzyme $F_{420}$, and NAD(P)H as electron carriers

\begin{tabular}{|c|c|c|c|c|c|c|c|}
\hline \multirow[t]{3}{*}{ Organism } & \multicolumn{7}{|c|}{ Hydrogenase and NADH:Fd oxidoreductase classification and corresponding genes } \\
\hline & \multicolumn{2}{|c|}{ [NiFe] $\mathrm{H}_{2}$ ase } & \multicolumn{4}{|c|}{ [FeFe] $\mathrm{H}_{2}$ ase } & \multirow{2}{*}{$\frac{\text { NFO }}{\text { rnf-type }}$} \\
\hline & $\begin{array}{l}\text { Fd-dependent ech } \\
\text { and } m b h^{\mathrm{G} 4}\end{array}$ & $\begin{array}{l}\mathrm{F}_{420^{-} \text {-dependent }}{ }^{\mathrm{G} 3} \\
\text { and other }{ }^{\mathrm{G} 1}\end{array}$ & Bifurcating & Sensory $^{A}$ & $\begin{array}{l}\mathrm{NAD}(\mathrm{P}) \mathrm{H}- \\
\text { dependent }\end{array}$ & $\begin{array}{l}\text { Fd- } \\
\text { dependent }\end{array}$ & \\
\hline $\begin{array}{l}\text { Standard free energy } \\
\left(\Delta G^{\circ}\right)^{*}\end{array}$ & -3.0 & 11 & $+7.5^{* *}$ & NA & 18.1 & 18.1 & $-21.1^{* * *}$ \\
\hline Ca. bescii DSM 6725 & Athe_1082-Athe_1087 & & $\begin{array}{l}\text { Athe_1297- } \\
\text { Athe_1299 A1 TR(M3) }\end{array}$ & Athe_1292 ${ }^{\text {D M2e }}$ & & & \\
\hline $\begin{array}{l}\text { Ca. saccharolyticus } \\
\text { DSM } 8903\end{array}$ & Csac_1534-Csac_1539 & & $\begin{array}{l}\text { Csac_1862- } \\
\text { Csac_1864 A1 TR(M3) }\end{array}$ & Csac_1857 D M2e & & & \\
\hline \multirow[t]{2}{*}{ P. furiosus DSM 3638} & PF1423- PF1436 & PF0891- PF0894 G3 & & & & & \\
\hline & & PF1329- PF1332 G3 & & & & & \\
\hline Th. kodakaraensis KOD1 & TK2080- TK2093 & TK2069-TK2072 G3 & & & & & \\
\hline T. neapolitana DSM 4359 & & & $\begin{array}{l}\text { CTN_1067- } \\
\text { CTN1069TH }\end{array}$ & $\begin{array}{l}\text { CTN_1071- } \\
\text { CTN_1072 CD(M2f) }\end{array}$ & CTN_0485 ${ }^{\mathrm{TH}}$ & & CTN_0437-CTN_0442 \\
\hline T. petrophila RKU-1 & & & Tpet_1367- Tpet_1369 TTH & $\begin{array}{l}\text { Tpet_1371- } \\
\text { Tpet_1372 CD(M2f) }\end{array}$ & Tpet_0723 ${ }^{T H}$ & & Tpet_0675-Tpet_0680 \\
\hline T. maritima MSB8 & & & TM1424- TM1426 ${ }^{\mathrm{TH}}$ & $\begin{array}{l}\text { TM1420- } \\
\text { TM1422 CD(M2f) }\end{array}$ & TM0201 THH & & TM0244- TM0249 \\
\hline \multirow{2}{*}{$\begin{array}{l}\text { Cal.subterraneus } \\
\text { subsp. tengcongensis } \\
\text { MB4 }\end{array}$} & TTE0123- TTE0134 & & TTE0892- TTE0894 A1 TR(M3) & TTE0887 D M2e & & & \\
\hline & & & & TTE0697 CD(M2f) & & & \\
\hline E. harbinense YUAN-3 T & & & $\begin{array}{l}\text { Ethha_2614- } \\
\text { Ethha_2616 A8 TR(M3) }\end{array}$ & Ethha_0052 CD(M2f) & Ethha_2293 A7 D(M3) & Ethha_0031 B2 M2a & \\
\hline \multirow[t]{3}{*}{ C. cellulolyticum $\mathrm{H} 10$} & Ccel_1686-Ccel_1691 & $\begin{array}{l}\text { Ccel_1070- } \\
\text { Ccel_1071 G1 }\end{array}$ & $\begin{array}{l}\text { Ccel_2303- } \\
\text { Ccel_2305 A8 TR(M3) }\end{array}$ & $\begin{array}{l}\text { Ccel_2300- } \\
\text { Ccel_2301 CD(M2f) }\end{array}$ & & Ethha_2695 B3 M3a & \\
\hline & Ccel_3363-Ccel_3371 & & $\begin{array}{l}\text { Ccel_2232- } \\
\text { Ccel_2234 A1 TR(M3) }\end{array}$ & & & & \\
\hline & & & $\begin{array}{l}\text { Ccel_2467- } \\
\text { Ccel_2468 A1 TR(M3) }\end{array}$ & & & & \\
\hline \multirow[t]{2}{*}{ C. phytofermentans ISDg } & Cphy_1730-Cphy_1735 & & $\begin{array}{l}\text { Cphy_0087- } \\
\text { Cphy_0089 A8 TR(M3) }\end{array}$ & $\begin{array}{l}\text { Cphy_0092- } \\
\text { Cphy_0093 CD(M2f) }\end{array}$ & & Cphy_2056 A5 M2C & Cphy_0211-Cphy_0216 \\
\hline & & & $\begin{array}{l}\text { Cphy_3803- } \\
\text { Cphy_3805 A1 TR(M3) }\end{array}$ & Cphy_3798 D M2e & $\begin{array}{l}\text { Cthe_3003- } \\
\text { Cthe_3004 }\end{array}$ & Cphy_0090 ${ }^{\text {B1 M3a }}$ & \\
\hline \multirow[t]{2}{*}{$\begin{array}{l}\text { C. thermocellum } \\
\text { ATCC } 27405\end{array}$} & Cthe_3013-Cthe_3024 & & $\begin{array}{l}\text { Cthe_0428- } \\
\text { Cthe_0430 A8 TR(M3) }\end{array}$ & $\begin{array}{l}\text { Cthe_0425- } \\
\text { Cthe_0426 } \\
\text { CD(M2f) }\end{array}$ & & & Cthe_2430-Cthe_2435 \\
\hline & & & $\begin{array}{l}\text { Cthe_0340- } \\
\text { Cthe_0342 A1 TR(M3) }\end{array}$ & & & & \\
\hline
\end{tabular}


Table 6 Genes encoding putative hydrogenases, sensory hydrogenases, and NADH:Fd oxidoreductases using ferredoxin, coenzyme $F_{420}$, and NAD(P)H as electron carriers (Continued)

$$
\text { Cthe_0335 }{ }^{\text {D M2e }}
$$

\begin{tabular}{|c|c|c|c|c|}
\hline C. thermocellum DSM 4150 & $\begin{array}{l}\text { CtherDRAFT_2162- } \\
\text { CtherDRAFT_2173 }\end{array}$ & $\begin{array}{l}\text { CtherDRAFT_1101- } \\
\text { CtherDRAFT } \\
1103 \text { A8 TR(MB) }\end{array}$ & $\begin{array}{ll}\text { CtherDRAFT_1098- } & \text { Yes }^{\mathrm{B}} \\
\text { CtherDRAFT_1099 CD(M2f) } & \end{array}$ & $\begin{array}{l}\text { CtherDRAFT_0369- } \\
\text { CtherDRAFT_0375 }\end{array}$ \\
\hline & & \multicolumn{3}{|c|}{ CtherDRAFT_2978 A1 TR(M3) } \\
\hline \multirow[t]{2}{*}{ Ta. pseudethanolicus 39E } & & & Teth39_0221 CD(M2f) & $\begin{array}{l}\text { Teth39_2119- } \\
\text { Teth39_2124 }\end{array}$ \\
\hline & & $\begin{array}{l}\text { Teth39_1456- } \\
\text { Teth39_1458 A1 TR(M3) }\end{array}$ & Teth39_1463 D M2e & \\
\hline
\end{tabular}

G. thermoglucosidasius C56-YS93

\section{B. cereus ATCC 14579}

${ }^{A}$ Group D M2e hydrogenases are poorly characterized and do not contain a PAS/PAC-sensory domain. However, given their proximity to protein kinases and bifurcating hydrogenases, and their phylogenetic proximity to group C D(M2f) sensory hydrogenases (Additional file 3) we have classified them as sensory hydrogenases.

Berified by microarray and proteomic analysis (unpublished).

Characterization of hydrogenase specificity was based metallocenter composition ([NiFe] or [FeFe]), modular structure, subunit composition, and large (catalytic) subunit phylogeny according to Vignais et al. and

Calusinska et al. [16,95,96]. Phylogenetic cluster groupings are indicated in superscript, and corresponding phylogenetic trees are provided in Additional file 1 and Additional file 2 . Abbreviations: $H_{2} a$ ase, hydrogenase; NFO, NADH:ferredoxin oxidoreductase; ech, energy conserving hydrogenase; mbh, membrane bound hydrogenase; rnf, Rhodobacter nitrogen fixation. 
file 2). Similarly, encoded [FeFe] $\mathrm{H}_{2}$ ases fell into 5 major subgroups including: (i) heterotrimeric bifurcating $\mathrm{H}_{2}$ ases, (ii) dimeric, $\mathrm{NAD}(\mathrm{P}) \mathrm{H}$-dependent uptake $\mathrm{H}_{2}$ ases, (iii) monomeric, putatively Fd-dependent $\mathrm{H}_{2}$ ases, (iv) dimeric sensory $\mathrm{H}_{2}$ ases containing PAS/PAC sensory domains which may be involved in redox sensing, and (v) monomeric sensory $\mathrm{H}_{2}$ ases (Additional file 3 ). These sensory $\mathrm{H}_{2}$ ases are usually encoded upstream of trimeric bifurcating $\mathrm{H}_{2}$ ases (Table 6) and are often separated by a histidine/ serine kinase suggesting a regulatory relationship between these two enzymes [16].

With the exception of P. furiosus and Th. kodakaranesis, which encode only Fd-dependent and putative $\mathrm{F}_{420^{-}}$ dependent [NiFe] $\mathrm{H}_{2}$ ases, all other $\mathrm{H}_{2}$ ase encoding organisms surveyed are capable of $\mathrm{H}_{2}$ ase-mediated oxidation/reduction of both Fd and $\mathrm{NAD}(\mathrm{P}) \mathrm{H}$. This seems fitting given that $P$. furiosus and Th. kodakaraensis preferentially catalyze the oxidation of glyceraldedhyde-3-P via GAPFOR rather than GAPDH and PGK, and thus must reoxidize reduced $\mathrm{Fd}$, rather than $\mathrm{NADH}$, during fermentative product synthesis. All other $\mathrm{H}_{2}$ ase encoding organisms produce $\mathrm{NADH}$ during glycolysis and reduced Fd via PFOR. In these organisms, the oxidation of these electron carriers may be carried out using various different types of $\mathrm{H}_{2}$ ases. All of these species encoded at least a single putative bifurcating $\mathrm{H}_{2}$ ase (Table 6). The majority of these bifurcating $\mathrm{H}_{2}$ ases were found downstream dimeric or monomeric sensory [FeFe] $\mathrm{H}_{2}$ ases that may be involved in their regulation (Table 6). Soboh et al. have demonstrated that NADHdependent $\mathrm{H}_{2}$ ase activities in Cal. subterraneus subsp. tengcongensis are affected by $\mathrm{H}_{2}$ partial pressures [42] suggesting possible regulation of these $\mathrm{H}_{2}$ ases via a twocomponent signal transduction mechanism in response changes in redox levels $[16,97]$. It is important to note that these $\mathrm{NADH}$-dependent $\mathrm{H}_{2}$ ase activities may reflect bifurcating $\mathrm{H}_{2}$ ase activities given that Cal. subterraneus subsp. tengcongensis encodes only a Fd-dependent and a putative bifurcating $\mathrm{H}_{2}$ ase, and no $\mathrm{NAD}(\mathrm{P}) \mathrm{H}$-dependent $\mathrm{H}_{2}$ ases.

While Ta. pseudethanolicus only encodes a bifurcating $\mathrm{H}_{2}$ ase, all other organisms that encode a bifurcating $\mathrm{H}_{2}$ ase also encode $\mathrm{Fd}$-dependent $\mathrm{H}_{2}$ ases. Putative Fddependent, [NiFe] Ech/Mbh-type $\mathrm{H}_{2}$ ases were identified in the genomes of Cal. subterraneus subsp. tengcongensis, P. furiosus, Th. kodakaraensis, and all Caldicellulosiruptor and Clostridium species (Table 6). A pair of putative $\mathrm{Fd}$-dependent [FeFe] $\mathrm{H}_{2}$ ases were identified in both $E$. harbinense and $C$. phytofermentans. With the exception of Ta. pseudethanolicus, Cal. subterraneus subsp. tengcongensis, and Caldicellulosiruptor species, all organisms surveyed containing a bifurcating $\mathrm{H}_{2}$ ase also appear to be capable of NADH and/or NADPH oxidation using NADH/NADPH-dependent $\mathrm{H}_{2}$ ases. As with ADHs, however, we could not determine $\mathrm{H}_{2}$ ase cofactor specificity exclusively using in silico sequence analysis, stressing the importance of activity characterization of enzyme substrate specificity. While C. cellulolyticum achieves $\mathrm{NAD}(\mathrm{P}) \mathrm{H}$ oxidation using a putative $\mathrm{H}_{2}$-uptake [NiFe] $\mathrm{H}_{2}$ ases, E. harbinense, Thermotoga species, and $C$. thermocellum ATCC 27405 achieve this using [FeFe] $\mathrm{H}_{2}$ ases. Although the draft genome of C. thermocellum DSM 4150 does not encode an NAD(P)H-dependent $\mathrm{H}_{2}$ ase, our proteomic and microarray data reveal the presence of Cthe_3003/Cthe_3004 homologues (Rydzak, unpublished results).

In addition to $\mathrm{H}_{2}$ ase-mediated electron transfer between Fd and/or NADH and $\mathrm{H}_{2}$, electrons may be transferred directly between Fd and $\mathrm{NAD}(\mathrm{P}) \mathrm{H}$ via an Rnf-like (Rhodobacter nitrogen fixation) NADH:ferredoxin oxidoreductase (NFO), a membrane-bound enzyme complex capable of generating a sodium motive force derived from the energy difference between reduced Fd and NADH. Only Thermotoga species, C. phytofermentans, C. thermocellum, and Ta. pseudethanolicus encode putatively identified NFO. Proteomic analysis of C. thermocellum, however, revealed low, or no, expression of NFO subunits, suggesting it does not play a major factor in electron exchange between Fd and NADH [100].

While the presence/absence of genes encoding pathways that lead to reduced fermentation products (i.e. formate, lactate, and particularly ethanol) is a major determinant of $\mathrm{H}_{2}$ yields, we can make some inferences with respect to $\mathrm{H}_{2}$ yields based on the types of $\mathrm{H}_{2}$ ases encoded. Given the thermodynamic efficiencies of $\mathrm{H}_{2}$ production using different cofactors, we can say that Fddependent $\mathrm{H}_{2}$ ases are conducive for $\mathrm{H}_{2}$ production while $\mathrm{NAD}(\mathrm{P}) \mathrm{H}$-dependent $\mathrm{H}_{2}$ ases are not. However, organisms that do not encode ethanol-producing pathways (i.e. Caldicellulosiruptor and Thermotoga species) may generate high intracellular $\mathrm{NADH}: \mathrm{NAD}^{+}$ratios, making NADH-dependent $\mathrm{H}_{2}$ production thermodynamically feasible under physiological conditions. Conversely, in organisms capable of producing both $\mathrm{H}_{2}$ and ethanol (Ethanoligenens, Clostridium, and Thermoanaerobacter species), the presence of Fddependent $\mathrm{H}_{2}$ ases appears to be beneficial for $\mathrm{H}_{2}$ production. For example, E. harbinense and Clostridium species, which encode Fd-dependent, as well as bifurcating and NAD $(\mathrm{P}) \mathrm{H}$-dependent $\mathrm{H}_{2}$ ases, produce much higher $\mathrm{H}_{2}$ yields when compared to those of Ta. pseudethanolicus, which encodes only one bifurcating $\mathrm{H}_{2}$ ase and no $\mathrm{Fd}$ or $\mathrm{NAD}(\mathrm{P}) \mathrm{H}$-dependent $\mathrm{H}_{2}$ ases. Interestingly, organisms that do not encode $\mathrm{H}_{2}$ ases (G. thermoglucosidasius and B. cereus) produce low ethanol and high lactate (and/or formate yields), suggesting that $\mathrm{H}_{2}$ production can help lower NADH: $\mathrm{NAD}^{+}$ratios, and thus reduce flux through LDH. 


\section{Influence of overall genome content on end-product profiles}

The presence and absence of genes encoding proteins involved in pyruvate metabolism and end-product synthesis may be used as an indicator of end-product distribution. By comparing genome content to end-product yields, we identified key markers that influence ethanol and $\mathrm{H}_{2}$ yields. These include (i) $\mathrm{MDH}$ (ii) $\mathrm{LDH}$, (iii) PFL vs. PFOR and/or PDH (iv) Aldh and AdhE, and (v) bifurcating, Fd-dependent, and $\mathrm{NAD}(\mathrm{P}) \mathrm{H}$ dependent $\mathrm{H}_{2}$ ase.

While it is difficult to elucidate how differences in "malate shunt" genes affect end-product synthesis patterns by comparing reported yields, eliminating $\mathrm{MDH}$ has been shown to increase lactate and ethanol production, and decrease acetate production in C. cellulolyticum [78]. The elimination of this transhydrogenation pathway may increase NADH:NAD ${ }^{+}$ratios for reduced end-product synthesis and reduce NADPH:NADP ${ }^{+}$ ratios for biosynthesis. While presence of LDH is not a good predictor of lactate yields, LDH, when activated, diverts reducing equivalents away from $\mathrm{H}_{2}$ and ethanol. In contrast to PFL, PFOR and PDH produce additional reducing equivalents (reduced $\mathrm{Fd}$ and $\mathrm{NADH}$, respectively), and thus promote reduced end-product synthesis. Organisms that do not encode pfl generally produce more ethanol and $\mathrm{H}_{2}$ (based on sum redox value) compared to those that do encode $p f l$. Of the organisms surveyed, those that did not encode (or express) both $a d h E$ and ald $H$ produced near-maximal $\mathrm{H}_{2}$ yields and little to no ethanol. While the type(s) of encoded $\mathrm{H}_{2}$ ases appear to have little impact in organisms that do not encode ethanol producing pathways, they do seem to influence reduced end-product yields in those that do. For example, Ta. pseudethanolicus, which encodes an adhE, NFO, and a single bifurcating $\mathrm{H}_{2}$ ase, but no discernable Fd or $\mathrm{NAD}(\mathrm{P}) \mathrm{H}$-dependent $\mathrm{H}_{2}$ ases, generates low $\mathrm{H}_{2}$ and near-optimal ethanol yields. The inability to oxidize reduced $\mathrm{Fd}$ via $\mathrm{Fd}$-dependent $\mathrm{H}_{2}$ ases may elevate reduced Fd levels, which in turn can be used by NFO to produce additional NADH for ethanol synthesis. Interestingly, in the absence of $\mathrm{H}_{2}$ ases, lactate production was favoured over ethanol production, suggesting that $\mathrm{H}_{2}$ production can help lower NADH:NAD ${ }^{+}$ratios, and thus reduce flux through $\mathrm{LDH}$.

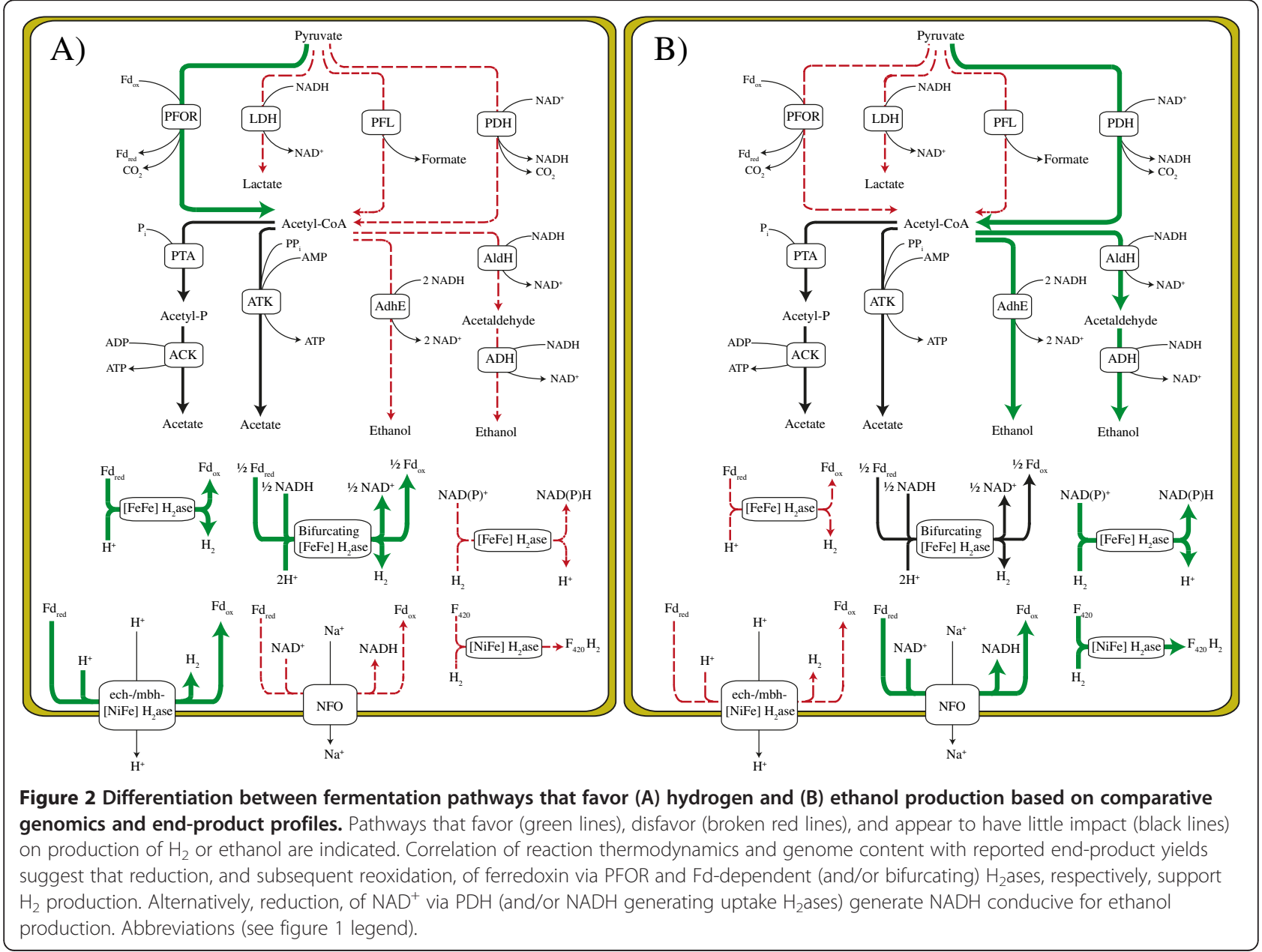


Given the impact that MDH, PFL, Aldh, AdhE, and the different $\mathrm{H}_{2}$ ases have on end-product yields, screening for these biomarkers can streamline ethanol and $\mathrm{H}_{2}$ producing potential of sequenced and novel organisms through in silico gene mining and the use of universal primers, respectively. Furthermore, understanding how end-product yields are affected by (i) the framework of genes encoding pathways catalyzing pyruvate into endproducts, and (ii) thermodynamic efficiencies of these reactions, we can begin to develop informed metabolic engineering strategies for optimization of either ethanol or $\mathrm{H}_{2}$ (Figure 2). For example, in order to optimize either ethanol or $\mathrm{H}_{2}$, we would recommend elimination of $l d h$ and $p f l$ in order to allow accumulation of additional reducing equivalents. Given that ethanol and $\mathrm{H}_{2}$ compete for reducing equivalents, elimination of one product should direct carbon/and or electron flux towards the other.

For optimization of $\mathrm{H}_{2}$ yields (Figure 2A), deletion of ald $H$ and $a d h E$ is likely most effective. Although conversion of pyruvate to acetyl-CoA is more thermodynamically favorable using $\mathrm{PDH}$ versus $\mathrm{PFOR}\left(\triangle \mathrm{G}^{\circ}=-33.4\right.$ vs. $-19.2 \mathrm{~kJ} \mathrm{~mol}^{-1}$ ), production of $\mathrm{H}_{2}$ from $\mathrm{NADH}$ is highly unfavorable compared to the use of reduced $\mathrm{Fd}\left(\triangle \mathrm{G}^{\circ}=\right.$ +18.1 vs. $-3.0 \mathrm{~kJ} \mathrm{~mol}^{-1}$ ). This in turn demonstrates that reduction of Fd via PFOR and subsequent $\mathrm{H}_{2}$ production via a Fd-dependent $\mathrm{H}_{2}$ ase $\left(\Delta^{\circ}{ }^{\circ}=-21.2 \mathrm{~kJ} \mathrm{~mol}^{-1}\right)$ is more favorable than NADH production via $\mathrm{PDH}$ and subsequent $\mathrm{H}_{2}$ production via $\mathrm{NAD}(\mathrm{P}) \mathrm{H}$-dependent $\mathrm{H}_{2}$ ases $\left(\triangle \mathrm{G}^{\circ}=-15.3 \mathrm{~kJ} \mathrm{~mol}^{-1}\right)$. Therefore, we propose that conversion of pyruvate to acetyl-CoA via PFOR is favorable for $\mathrm{H}_{2}$ production, and $p d h$ (and $p f l$ ) should be deleted. Given that $2 \mathrm{NADH}$ (per glucose) are produced during glycolysis in most anaerobic microorganisms, the presence of a bifurcating $\mathrm{H}_{2}$ ase, which would simultaneously oxidize the $2 \mathrm{NADH}$ generated during and 2 reduced Fd produced by PFOR, would be required to achieve theoretically maximal $\mathrm{H}_{2}$ yields of $4 \mathrm{~mol}$ per mol glucose. A Fd-dependent $\mathrm{H}_{2}$ ase would also be conducive for $\mathrm{H}_{2}$ production during times when reducing equivalents generated during glycolysis are redirected towards biosynthetic pathways, resulting in a disproportionate ratio of reduced ferredoxin to $\mathrm{NAD}(\mathrm{P}) \mathrm{H}$. Alternatively, in organisms such as P. furiosus and Th. kodakaraensis, which generate high levels of reduced Fd and low levels of $\mathrm{NADH}$, the presence of $\mathrm{Fd}$-dependent $\mathrm{H}_{2}$ ases, rather than bifurcating $\mathrm{H}_{2}$ ases, would be more conducive for $\mathrm{H}_{2}$ production. In all cases, NFO and $\mathrm{NAD}(\mathrm{P}) \mathrm{H}-$ dependent $\mathrm{H}_{2}$ ases should be deleted to prevent oxidation of reduced Fd and uptake of $\mathrm{H}_{2}$, respectively, which would generate $\mathrm{NAD}(\mathrm{P}) \mathrm{H}$.

The metabolic engineering strategies employed for optimization of ethanol (Figure 2B) are much different than those used for the production of $\mathrm{H}_{2}$. First, adhE and/or ald $H$ and adh genes that encode enzymes with high catalytic efficiencies in the direction of ethanol formation should be heterologously expressed. Given that ethanol production is $\mathrm{NAD}(\mathrm{P}) \mathrm{H}$ dependent, increasing NADH production should be optimized, while Fd reduction should be eliminated. Through deletion of $p f l$ and pfor, and expression of $p d h$, up to 4 NADH can be generated per glucose, allowing for the theoretical maximum of $2 \mathrm{~mol}$ ethanol per mol glucose to be produced. To prevent NADH reoxidation, lactate and $\mathrm{H}_{2}$ production should be eliminated by deleting $l d h$ and NAD(P) $\mathrm{H}$-dependent $\mathrm{H}_{2}$ ases. While this strategy is theoretically sound, low AldH/Adh catalytic efficiencies may cause $\mathrm{NADH} / \mathrm{NAD}^{+}$ratios to rise so high that they may impede glycolysis. In these situations, the presence of a NFO or NAD(P)H-dependent $\mathrm{H}_{2}$ ase may intermittently alleviate these high $\mathrm{NADH} / \mathrm{NAD}^{+}$ratios through generation of reduced Fd pools or $\mathrm{H}_{2}$ production, respectively, albeit it would decrease reducing equivalents for ethanol production.

While some attempts to increase $\mathrm{H}_{2}$ and/or ethanol yields through genetic engineering have been successful in a number of lignocellulolytic organisms (reviewed elsewhere; [101]) engineering of strains discussed here has only been marginally successful. Heterologous expression of Zymomonas mobilis pyruvate decarboxylase and Adh in C. cellulolyticum increased cellulose consumption and biomass production, and decreased lactate production and pyruvate overflow due to a more efficient regulation of carbon and electron flow at the pyruvate branchpoint [102]. However, despite higher levels of total ethanol produced, ethanol yields (per mol hexose consumed) actually decreased when compared to the wild-type strain. Similarly, deletion of PTA in C. thermocellum drastically reduced acetate production, but had minimal impact on lactate or ethanol production [103]. This suggests that genome content alone cannot exclusively dictate the extent of end-product yields observed in literature, and thus growth conditions must be optimized in order to moderate regulatory mechanisms that direct carbon and electron flux. This could only be attained through a thorough understanding of regulatory mechanisms that mediate gene and gene-product expression and activity levels under various growth conditions through a combination of genomics, transcriptomics, proteomics, metabolomics, and enzyme characterization.

\section{Conclusions}

Fermentative bacteria offer the potential to convert biomass into renewable biofuels such as $\mathrm{H}_{2}$ and ethanol through consolidated bioprocessing. However, these bacteria display highly variable, branched catabolic pathways that divert carbon and electrons towards unwanted end products (i.e. lactate, formate). In order to make 
fermentative $\mathrm{H}_{2}$ and/or ethanol production more economically feasible, biofuel production yields must be increased in lignocellulolytic bacteria capable of consolidated bioprocessing. While the cellulolytic and, to a lesser extent, $\mathrm{H}_{2}$ and ethanol producing capabilities of cellulolytic bacteria have been reviewed $[8,9,44]$, a comprehensive comparison between genome content and corresponding end-product distribution patterns has not been reported. While reported end-product yields vary considerably in response to growth conditions, which may influence gene and gene product expression and metabolic flux, we demonstrate that composition of genes encoding pyruvate catabolism and end-product synthesis pathways alone can be used to approximate potential end-product distribution patterns. We have identified a number of genetic biomarkers, including (i) MDH (ii) LDH, (iii) PFL vs. PFOR and/ or PDH (iv) Aldh and AdhE, and (V) bifurcating, Fddependent, and $\mathrm{NAD}(\mathrm{P}) \mathrm{H}$ dependent $\mathrm{H}_{2}$ ases, that can be used for streamlining $\mathrm{H}_{2}$ and/or ethanol producing capabilities in sequenced and novel isolates. By linking genome content, reaction thermodynamics, and end-product yields, we offer potential targets for optimization of either ethanol or $\mathrm{H}_{2}$ yields via metabolic engineering. Deletion of LDH and PFL could potentially increase both $\mathrm{H}_{2}$ and ethanol yields. While deletion of ethanol producing pathways (aldH, adh, adhE), increasing flux through PFOR, overexpression of $\mathrm{Fd}$-dependent $\mathrm{H}_{2}$ ases, and elimination of potential $\mathrm{H}_{2}$-uptake (NAD(P)H-dependent) $\mathrm{H}_{2}$ ases could lead to increased $\mathrm{H}_{2}$ production, eliminating $\mathrm{H}_{2}$ production and redirecting flux through PDH would be beneficial for ethanol production. Although gene and gene-product expression, functional characterization, and metabolomic flux analysis remains critical in determining pathway utilization, insights regarding how genome content affects end-product yields can be used to direct metabolic engineering strategies and streamline the characterization of novel species with potential industrial applications.

\section{Additional files}

\section{Additional file 1: Cofactor specificity (ATP or $\mathrm{PP}_{\mathrm{i}}$ ) of} phosphofructokinases based on sequence alignments. Alignments of key residues determining ATP or PP $_{i}$ specificity, as determined by Bapteste et al. [74] and Bielen et al. [75], were performed using BioEdit v.7.0.9.0. The $P$. furiosus and Th. kodakarensis genes are very distinct (different COG and different $\mathrm{KO}$ ) and are annotated as Archaeal phosphofructokinases.

Additional file 2: Phylogenetic clustering of [NiFe] hydrogenases large (catalytic) subunits. Catalytic (large) subunits of [NiFe] $\mathrm{H}_{2}$ ases were identified based upon the modular signatures as described by Calusinska et al. [16], Species considered in this manuscript are highlighted and corresponding $\mathrm{H}_{2}$ ase gene loci are provided.

Additional file 3: Phylogenetic clustering of [FeFe] hydrogenases large (catalytic) subunits. Catalytic (large) subunits of [FeFe] $\mathrm{H}_{2}$ ases were identified based upon the modular signatures as described by
Calusinska et al. [16]. Species considered in this manuscript are highlighted and corresponding $\mathrm{H}_{2}$ ase gene loci are provided.

\section{Abbreviations}

ACK: Acetate kinase; ADH: Alcohol dehydrogenase; AdhE: Acetaldehyde/ alcohol dehydrogenase (bifunctional); AldH: Aldehyde dehydrogenase; ATK: Acetate thiokinase; Ech: Energy conserving hydrogenase; Fd: Ferredoxin; FDP: Fructose-1,6-bisphosphate; FHL: Formate hydrogen lyase; GAPDH: Glyceraldehyde-3-phosphate dehydrogenase:

GAPFOR: Glyceraldehydes-3-phosphate ferredoxin oxidoreductase; $\mathrm{H}_{2}$ ase: Hydrogenase; IMG: Integrated Microbial Genomes; KO: KEGG Orthology; LDH: Lactate dehydrogenase; MalE: Malic enzyme; Mbh: Membrane-bound hydrogenase; $\mathrm{MDH}$ : Malate dehydrogenase; NFO: NADH:ferredoxin oxidoreductase; O/R: (Oxidation/reduction); OAADC: Oxaloacetate decarboxylase; PDH: Pyruvate dehydrogenase; PEP: Phosphoenolpyruvate; PEPCK: Phosphoenolpyruvate carboxykinase; PFK: Phosphofructokinase; PFL: Pyruvate:formate lyase; PFOR: Pyruvate: ferredoxin oxidoreductase; PGK: Phosphoglycerate kinase; PPDK: Pyruvate phosphate dikinase; PPK: Pyruvate kinase; PTA: Phosphotransacetylase; Rnf: Rhodobacter nitrogen fixation; $\mathrm{RV}_{\mathrm{EP}}$ : Total molar reduction values of reduced end-products $\left(\mathrm{H}_{2}+\right.$ ethanol).

\section{Authors' contributions}

TR and CRC co-authored the manuscript. TV, CRC and TR performed genomic meta-analysis. TR performed end-product comparisons and thermodynamic calculations. CRC performed phylogenetic analysis. RS, NC, and DBL conceived of the study, participated in its design, and helped draft the manuscript. All authors read and approved the final manuscript.

\section{Acknowledgements}

This work was supported by funds provided by the Natural Sciences and Engineering Research Council of Canada (NSERC), through a Strategic Programs grant (STPGP 306944-04), by Genome Canada, through the Applied Genomics Research in Bioproducts or Crops (ABC) program for the grant titled, "Microbial Genomics for Biofuels and CoProducts from Biorefining Processes", and by the Province of Manitoba, Agricultural and Rural Development Initiative (ARDI), grant 09-986.

\section{Author details}

${ }^{1}$ Department of Biosystems Engineering, University of Manitoba, Winnipeg, MB, Canada R3T 5V6. ' ${ }^{2}$ eppartment of Microbiology, University of Manitoba, Winnipeg, MB, Canada R3T 5V6.

Received: 12 November 2012 Accepted: 12 December 2012 Published: 18 December 2012

\section{References}

1. Carere C, Kalia V, Sparling R, Cicek N, Levin D: Pyruvate catabolism and hydrogen synthesis pathway genes of Clostridium thermocellum ATCC 27405. Indian J Microbiol 2008, 48(2):252-266.

2. Levin DB, Pitt L, Love M: Biohydrogen production: prospects and limitations to practical application. Int J Hydrogen Energy 2004, 29(2):173-185.

3. Lynd LR, van Zyl WH, McBride JE, Laser M: Consolidated bioprocessing of cellulosic biomass: an update. Curr Opin Biotechnol 2005, 16(5):577-583.

4. Desvaux M: Clostridium cellulolyticum: model organism of mesophillic cellulolytic clostridia. FEMS Microbiol Rev 2005, 29:741-764.

5. Islam R, Cicek N, Sparling R, Levin D: Influence of initial cellulose concentration on the carbon flow distribution during batch fermentation by Clostridium thermocellum ATCC 27405. Appl Microbiol Biotechnol 2009, 82(1):141-148.

6. Yang SJ, Kataeva I, Hamilton-Brehm SD, Engle NL, Tschaplinski TJ, Doeppke C, Davis M, Westpheling J, Adams MWW: Efficient degradation of lignocellulosic plant biomass, without pretreatment, by the thermophilic anaerobe "anaerocellum thermophilum" DSM 6725. Appl Environ Microbiol 2009, 75(14):4762-4769.

7. Hallenbeck PC, Benemann JR: Biological hydrogen production; fundamentals and limiting processes. Int J Hydrogen Energy 2002, 27:1123-1505.

8. Bruggemann H, Gottschalk G: Comparative genomics of clostridia: link between the ecological niche and cell surface properties. Ann N Y Acad Sci 2008, 1125:73-81. 
9. Desvaux M: Unravelling carbon metabolism in anaerobic cellulolytic bacteria. Biotechnol Prog 2006, 22(5):1229-1238.

10. Rydzak T, Levin DB, Cicek N, Sparling R: Growth phase-dependant enzyme profile of pyruvate catabolism and end-product formation in Clostridium thermocellum ATCC 27405. J Biotechnol 2009, 140(3-4):169-175.

11. Markowitz VM, Korzeniewski F, Palaniappan K, Szeto E, Werner G, Padki A Zhao X, Dubchak I, Hugenholtz P, Anderson I, et al: The integrated microbial genomes (IMG) system. Nucleic Acids Res 2006, 34(Database issue):D344-D348.

12. Tatusov RL, Fedorova ND, Jackson JD, Jacobs AR, Kiryutin B, Koonin EV, Krylov DM, Mazumder R, Mekhedov SL, Nikolskaya AN, et al: The COG database: an updated version includes eukaryotes. BMC Bioinformatics 2003, 4:41

13. Kanehisa M, Araki M, Goto S, Hattori M, Hirakawa M, Itoh M, Katayama T, Kawashima S, Okuda S, Tokimatsu T, et al: KEGG for linking genomes to life and the environment. Nucleic Acids Res 2008, 36(Database issue):D480-D484.

14. Haft DH, Loftus BJ, Richardson DL, Yang F, Eisen JA, Paulsen IT, White O: TIGRFAMs: a protein family resource for the functional identification of proteins. Nucleic Acids Res 2001, 29(1):41-43.

15. Altschul SF, Gish W, Miller W, Myers EW, Lipman DJ: Basic local alignment search tool. J Mol Biol 1990, 215(3):403-410.

16. Calusinska M, Happe $T$, Joris B, Wilmotte A: The surprising diversity of clostridial hydrogenases: a comparative genomic perspective. Microbiology 2010, 156(Pt 6):1575-1588.

17. Saitou N, Nei M: The neighbor-joining method: a new method for reconstructing phylogenetic trees. Mol Biol Evol 1987, 4(4):406-425

18. Felsenstein J: Confidence limits on phylogenies: an approach using the bootstrap. Evolution 1985, 39(4):783-791.

19. Zuckerkandl E, Pauling L: Evolutionary divergence and convergence in proteins. In Evolving Genes and Proteins. Edited by Bryson V, Vogel H. New York: Academic Press; 1965:97-166.

20. Tamura K, Peterson D, Peterson N, Stecher G, Nei M, Kumar S: MEGA5: molecular evolutionary genetics analysis using maximum likelihood, evolutionary distance, and maximum parsimony methods. Mol Biol Evol 2011, 28(10):2731-2739.

21. Thauer RK, Jungermann K, Decker K: Energy conservation in chemotrophic anaerobic bacteria. Bacteriol Rev 1977, 41(1):100-180.

22. Chemical Rubber Company: CRC handbook of chemistry and physics. Cleveland, OH: CRC Press; 1977

23. Hall TA: BioEdit: a user-friendly biological sequence alignment editor and analysis program for Windows 95/98/NT. Nucleic Acids Symp Ser 1999, 1999:95-98

24. de Vrije T, Mars AE, Budde MAW, Lai MH, Dijkema C, de Waard P, Claassen PAM: Glycolytic pathway and hydrogen yield studies of the extreme thermophile Caldicellulosiruptor saccharolyticus. Appl Microbiol Biotechnol 2007, 74(6):1358-1367.

25. Bredholt S, Sonne-Hansen J, Nielsen P, Mathrani IM, Ahring BK: Caldicellulosiruptor kristjanssonii sp nov., a cellulolytic extremely thermophilic, anaerobic bacterium. Int J Syst Bacteriol 1999, 49:991-996.

26. Kadar Z, De Vrijek T, van Noorden GE, Budde MAW, Szengyel Z, Reczey K, Claassen PAM: Yields from glucose, xylose, and paper sludge hydrolysate during hydrogen production by the extreme thermophile Caldicellulosiruptor saccharolyticus. Appl Biochem Biotechnol 2004 113-16:497-508.

27. Kataeva IA, Yang SJ, Dam P, Poole FL, Yin Y, Zhou FF, Chou WC, Xu Y, Goodwin $L$, Sims DR, et al: Genome sequence of the anaerobic, thermophilic, and cellulolytic bacterium "anaerocellum thermophilum" DSM 6725. J Bacteriol 2009, 191(11):3760-3761.

28. Svetlichnyi VA, Svetlichnaya TP, Chernykh NA, Zavarzin GA: Anaerocellumthermophilum Gen-Nov Sp-Nov - an extremely thermophilic cellulolytic eubacterium isolated from hot-springs in the Valley of Geysers. Microbiology 1990, 59(5):598-604.

29. Chou CJ, Shockley KR, Conners SB, Lewis DL, Comfort DA, Adams MW, Kelly RM: Impact of substrate glycoside linkage and elemental sulfur on bioenergetics of and hydrogen production by the hyperthermophilic archaeon Pyrococcus furiosus. Appl Environ Microbiol 2007, 73(21):6842-6853.

30. Kengen SW, de Bok FA, van Loo ND, Dijkema C, Stams AJ, de Vos WM: Evidence for the operation of a novel Embden-Meyerhof pathway that involves ADP-dependent kinases during sugar fermentation by Pyrococcus furiosus. J Biol Chem 1994, 269(26):17537-17541.
31. Schicho RN, Ma K, Adams MW, Kelly RM: Bioenergetics of sulfur reduction in the hyperthermophilic archaeon Pyrococcus furiosus. J Bacteriol 1993, 175(6):1823-1830

32. Kanai T, Imanaka H, Nakajima A, Uwamori K, Omori $Y$, Fukui T, Atomi H, Imanaka T: Continuous hydrogen production by the hyperthermophilic archaeon, Thermococcus kodakaraensis KOD1. J Biotechnol 2005, 116(3):271-282.

33. Munro SA, Zinder SH, Walker LP: The fermentation stoichiometry of Thermotoga neapolitana and influence of temperature, oxygen, and $\mathrm{pH}$ on hydrogen production. Biotechnol Prog 2009, 25(4):1035-1042.

34. Nguyen TA, Han SJ, Kim JP, Kim MS, Sim SJ: Hydrogen production of the hyperthermophilic eubacterium, Thermotoga neapolitana under N2 sparging condition. Bioresour Technol 2010, 101(Suppl 1):S38-S41.

35. Eriksen NT, Nielsen TM, Iversen N: Hydrogen production in anaerobic and microaerobic Thermotoga neapolitana. Biotechnol Lett 2008, 30(1):103-109.

36. Takahata $Y$, Nishijima M, Hoaki T, Maruyama T: Thermotoga petrophila sp. nov. and Thermotoga naphthophila sp. nov., two hyperthermophilic bacteria from the Kubiki oil reservoir in Niigata, Japan. Int J Syst Evol Microbiol 2001, 51(Pt 5):1901-1909.

37. Nguyen TN, Borges KM, Romano AH, Noll KM: Differential gene expression in Thermotoga neapolitana in response to growth substrate. FEMS Microbiol Lett 2001, 195(1):79-83.

38. Schröder C, Selig M, Schönheit P: Glucose fermentation to acetate, $\mathrm{CO}_{2}$, and $\mathrm{H}_{2}$ in the anaerobic hyperthermophilic eubacterium thermotoga maritima: involvement of the embden-meyerhof pathway. Arch Microbiol 1994, 161(6):460-470.

39. Lakhal R, Auria R, Davidson S, Ollivier B, Dolla A, Hamdi M, Combet-Blanc $Y$ : Effect of oxygen and redox potential on glucose fermentation in thermotoga maritima under controlled physicochemical conditions. Int J Microbiol 2010, 2010:896510.

40. Nguyen TAD, Pyo Kim J, Sun Kim M, Kwan Oh Y, Sim SJ: Optimization of hydrogen production by hyperthermophilic eubacteria, thermotoga maritima and thermotoga neapolitana in batch fermentation. Int J Hydrogen Energy 2008, 33(5):1483-1488.

41. Xue $Y, X u Y$, Liu $Y, M a Y$, Zhou P: Thermoanaerobacter tengcongensis sp. nov., a novel anaerobic, saccharolytic, thermophilic bacterium isolated from a hot spring in Tengcong, China. Int J Syst Evol Microbiol 2001, 51(Pt 4):1335-1341.

42. Soboh B, Linder D, Hedderich R: A multisubunit membrane-bound [NiFe] hydrogenase and an NADH-dependent Fe-only hydrogenase in the fermenting bacterium Thermoanaerobacter tengcongensis. Microbiology 2004, 150(7):2451-2463.

43. Xing D, Ren N, Li Q, Lin M, Wang A, Zhao L: Ethanoligenens harbinense gen. nov., sp. nov., isolated from molasses wastewater. Int J Syst Evol Microbiol 2006, 56(Pt 4):755-760.

44. Ren Z, Ward TE, Logan BE, Regan JM: Characterization of the cellulolytic and hydrogen-producing activities of six mesophilic Clostridium species. J Appl Microbiol 2007, 103(6):2258-2266.

45. Warnick TA, Methe BA, Leschine SB: Clostridium phytofermentans sp. nov., a cellulolytic mesophile from forest soil. Int J Syst Evol Microbiol 2002, 52(Pt 4):1155-1160.

46. Islam R, Cicek N, Sparling R, Levin D: Effect of substrate loading on hydrogen production during anaerobic fermentation by Clostridium thermocellum 27405. Appl Microbiol Biotechnol 2006, 72(3):576-583.

47. Freier D, Mothershed CP, Wiegel J: Characterization of Clostridium thermocellum JW20. App/ Environ Microbiol 1988, 54(1):204-211.

48. Lacis LS, Lawford HG: Ethanol-production from xylose by thermoanaerobacter-ethanolicus in batch and continuous culture. Arch Microbiol 1988, 150(1):48-55.

49. Lacis LS, Lawford HG: Thermoanaerobacter ethanolicus growth and product yield from elevated levels of xylose or glucose in continuous cultures. App/ Environ Microbiol 1991, 57(2):579-585.

50. Wiegel J, Ljungdahl LG: Thermoanaerobacter ethanolicus gen. nov., spec. nov., a new, extreme thermophilic, anaerobic bacterium. Arch Microbiol 1981, 128(4):343-348.

51. Ouhib-Jacobs $O$, Lindley ND, Schmitt $P$, Clavel T: Fructose and glucose mediates enterotoxin production and anaerobic metabolism of Bacillus cereus ATCC14579(T). J Appl Microbiol 2009, 107(3):821-829.

52. Tang YJ, Sapra R, Joyner D, Hazen TC, Myers S, Reichmuth D, Blanch $H$, Keasling JD: Analysis of metabolic pathways and fluxes in a newly 
discovered thermophilic and ethanol-tolerant Geobacillus strain. Biotechnol Bioeng 2009, 102(5):1377-1386.

53. Stevenson DM, Weimer PJ: Expression of 17 genes in Clostridium thermocellum ATCC 27405 during fermentation of cellulose or cellobiose in continuous culture. App/ Environ Microbio/ 2005, 71(8):4672-4678

54. Strobel HJ: Growth of the thermophilic bacterium Clostridium thermocellum in continuous culture. Curr Microbiol 1995, 31(4):210-214.

55. Guedon E, Payot S, Desvaux M, Petitdemange H: Carbon and electron flow in Clostridium cellulolyticum grown in chemostat culture on synthetic medium. J Bacterio/ 1999, 181(10):3262-3269.

56. Özkan M, Ylmaz E, Lynd LR, Özcengiz G: Cloning and expression of the Clostridium thermocellum L-lactate dehydrogenase in Escherichia coli and enzyme characterization. Can J Microbiol 2004, 50:845-851.

57. Willquist K, Zeidan AA, van Niel EW: Physiological characteristics of the extreme thermophile Caldicellulosiruptor saccharolyticus: an efficient hydrogen cell factory. Microb Cell Fact 2010, 9:89.

58. Desvaux M, Guedon E, Petitdemange $\mathrm{H}$ : Metabolic flux in cellulose batch and cellulose-fed continuous cultures of Clostridium cellulolyticum in response to acidic environment. Microbiology 2001, 147(Pt 6):1461-1471.

59. Desvaux M, Petitdemange H: Flux analysis of the metabolism of Clostridium cellulolyticum grown in cellulose-fed continuous culture on a chemically defined medium under ammonium-limited conditions. Appl Environ Microbiol 2001, 67(9):3846-3851.

60. Desvaux M, Guedon E, Petitdemange H: Kinetics and metabolism of cellulose degradation at high substrate concentrations in steady-state continuous cultures of Clostridium cellulolyticum on a chemically defined medium. Appl Environ Microbiol 2001, 67(9):3837-3845.

61. Guedon E, Payot S, Desvaux M, Petitdemange H: Relationships between cellobiose catabolism, enzyme levels, and metabolic intermediates in Clostridium cellulolyticum grown in a synthetic medium. Biotechnol Bioeng 2000, 67(3):327-335.

62. Ben-Bassat A, Lamed R, Zeikus JG: Ethanol production by thermophilic bacteria: metabolic control of end product formation in Thermoanaerobium brockii. J Bacteriol 1981, 146(1):192-199.

63. Levin DB, Islam R, Cicek N, Sparling R: Hydrogen production by Clostridium thermocellum 27405 from cellulosic biomass substrates. Int J Hydrogen Energy 2006, 31(11):1496-1503.

64. Strobel HJ, Caldwell FC, Dawson KA: Carbohydrate transport by the anaerobic thermophile Clostridium thermocellum LQRI. Appl Environ Microbiol 1995, 61(11):4012-4015.

65. Zhang YH, Lynd LR: Regulation of cellulase synthesis in batch and continuous cultures of Clostridium thermocellum. J Bacterio/ 2005, 187(1):99-106

66. Girbal L, Soucaille P: Regulation of Clostridium acetobutylicum metabolism as revealed by mixed-substrate steady-state continuous cultures: role of NADH/NAD ratio and ATP pool. J Bacteriol 1994, 176(21):6433-6438.

67. Vasconcelos I, Girbal L, Soucaille P: Regulation of carbon and electron flow in Clostridium acetobutylicum grown in chemostat culture at neutral $\mathrm{pH}$ on mixtures of glucose and glycerol. J Bacteriol 1994, 176(5):1443-1450

68. Ml D, Guedon E, Petitdemange H: Metabolic flux in cellulose batch and cellulose-fed continuous cultures of Clostridium cellulolyticum in response to acidic environment. Microbiology 2001, 147(6):1461-1471.

69. Lamed RJ, Lobos JH, Su TM: Effects of stirring and hydrogen on fermentation products of Clostridium thermocellum. Appl Environ Microbiol 1988, 54(5):1216-1221

70. Bothun GD, Knutson BL, Berberich JA, Strobel HJ, Nokes SE: Metabolic selectivity and growth of Clostridium thermocellum in continuous culture under elevated hydrostatic pressure. App/ Microbiol Biotechnol 2004, 65(2):149-157.

71. Lamed R, Zeikus JG: Ethanol production by thermophilic bacteria: relationship between fermentation product yields of and catabolic enzyme activities in Clostridium thermocellum and Thermoanaerobium brockii. J Bacteriol 1980, 144(2):569-578.

72. Rydzak T, Levin DB, Cicek N, Sparling R: End-product induced metabolic shifts in Clostridium thermocellum ATCC 27405. Appl Microbiol Biotechnol 2011, 92(1):199-209.

73. Sauer U, Eikmanns BJ: The PEP-pyruvate-oxaloacetate node as the switch point for carbon flux distribution in bacteria. FEMS Microbiol Rev 2005, 29(4):765-794.

74. Bapteste E, Moreira D, Philippe H: Rampant horizontal gene transfer and phospho-donor change in the evolution of the phosphofructokinase. Gene 2003, 318:185-191.
75. Bielen AAM, Willquist K, Engman J, Van Der Oost J, Van Niel EWJ, Kengen SWM: Pyrophosphate as a central energy carrier in the hydrogen-producing extremely thermophilic Caldicellulosiruptor saccharolyticus. FEMS Microbiol Lett 2010, 307(1):48-54

76. Mukund S, Adams MW: Glyceraldehyde-3-phosphate ferredoxin oxidoreductase, a novel tungsten-containing enzyme with a potential glycolytic role in the hyperthermophilic archaeon Pyrococcus furiosus. J Biol Chem 1995, 270(15):8389-8392.

77. Gowen CM, Fong SS: Genome-scale metabolic model integrated with RNAseq data to identify metabolic states of Clostridium thermocellum. Biotechnol J 2010, 5(7):759-767.

78. Li Y, Tschaplinski TJ, Engle NL, Hamilton CY, Rodriguez M Jr, Liao JC, Schadt CW, Guss AM, Yang Y, Graham DE: Combined inactivation of the Clostridium cellulolyticum lactate and malate dehydrogenase genes substantially increases ethanol yield from cellulose and switchgrass fermentations. Biotechnol Biofuels 2012, 5(1):2.

79. Axley MJ, Grahame DA, Stadtman TC: Escherichia coli formate-hydrogen lyase. Purification and properties of the selenium-dependent formate dehydrogenase component. J Biol Chem 1990, 265(30):18213-18218.

80. Garvie El: Bacterial lactate dehydrogenases. Microbiol Rev 1980, 44(1):106-139.

81. van de Werken $H J$, Verhaart MR, VanFossen AL, Willquist $K$, Lewis $D L$, Nichols JD, Goorissen HP, Mongodin EF, Nelson KE, van Niel EW, et al: Hydrogenomics of the extremely thermophilic bacterium Caldicellulosiruptor saccharolyticus. Appl Environ Microbiol 2008, 74(21):6720-6729.

82. Membrillo-Hernandez J, Echave P, Cabiscol E, Tamarit J, Ros J, Lin EC Evolution of the adhE gene product of Escherichia coli from a functional reductase to a dehydrogenase. Genetic and biochemical studies of the mutant proteins. J Biol Chem 2000, 275(43):33869-33875.

83. Zhu J, Shimizu K: Effect of a single-gene knockout on the metabolic regulation in Escherichia coli for D-lactate production under microaerobic condition. Metab Eng 2005, 7(2):104-115

84. Asanuma $\mathrm{N}$, Hino $\mathrm{T}$ : Effects of $\mathrm{pH}$ and energy supply on activity and amount of pyruvate formate-lyase in Streptococcus bovis. Appl Environ Microbiol 2000, 66(9):3773-3777

85. Asanuma N, Yoshii T, Hino T: Molecular characteristics and transcription of the gene encoding a multifunctional alcohol dehydrogenase in relation to the deactivation of pyruvate formate-lyase in the ruminal bacterium Streptococcus bovis. Arch Microbiol 2004, 181(2):122-128.

86. Brown SD, Guss AM, Karpinets TV, Parks JM, Smolin N, Yang S, Land ML, Klingeman DM, Bhandiwad A, Rodriguez M Jr, et al: Mutant alcohol dehydrogenase leads to improved ethanol tolerance in Clostridium thermocellum. Proc Natl Acad Sci USA 2011, 108(33):13752-13757.

87. Trinh CT, Li J, Blanch HW, Clark DS: Redesigning Escherichia coli metabolism for anaerobic production of isobutanol. Appl Environ Microbiol 2011, 77(14):4894-4904.

88. Liu X, Dong Y, Zhang J, Zhang A, Wang L, Feng L: Two novel metalindependent long-chain alkyl alcohol dehydrogenases from Geobacillus thermodenitrificans NG80-2. Microbiology 2009, 155(Pt 6):2078-2085.

89. Pei J, Zhou Q, Jiang Y, Le Y, Li H, Shao W, Wiegel J: Thermoanaerobacter spp. control ethanol pathway via transcriptional regulation and versatility of key enzymes. Metab Eng 2010, 12(5):420-428.

90. Burdette D, Zeikus JG: Purification of acetaldehyde dehydrogenase and alcohol dehydrogenases from Thermoanaerobacter ethanolicus $39 \mathrm{E}$ and characterization of the secondary-alcohol dehydrogenase (2 degrees Adh) as a bifunctional alcohol dehydrogenase-acetyl-CoA reductive thioesteras. Biochem J 1994, 302(Pt 1):163-170.

91. Lovitt RW, Shen GJ, Zeikus JG: Ethanol production by thermophilic bacteria: biochemical basis for ethanol and hydrogen tolerance in Clostridium thermohydrosulfuricum. J Bacteriol 1988, 170(6):2809-2815.

92. Bernard N, Johnsen K, Holbrook JJ, Delcour J: D175 Discriminates between $\mathrm{NADH}$ and NADPH in the coenzyme binding site of Lactobacillus delbrueckii subsp. bulgaricus D-lactate dehydrogenase. Biochem Biophys Res Commun 1995, 208(3):895-900.

93. Nair RV, Bennett GN, Papoutsakis ET: Molecular characterization of an aldehyde/alcohol dehydrogenase gene from Clostridium acetobutylicum ATCC 824. J Bacteriol 1994, 176(3):871-885.

94. Hamilton-Brehm SD, Mosher JJ, Vishnivetskaya T, Podar M, Carroll S, Allman S, Phelps TJ, Keller M, Elkins JG: Caldicellulosiruptor obsidiansis sp. nov., an anaerobic, extremely thermophilic, cellulolytic bacterium isolated from 
Obsidian Pool, Yellowstone National Park. Appl Environ Microbiol 2009, 76(4):1014-1020

95. Vignais PM, Billoud B, Meyer J: Classification and phylogeny of hydrogenases. FEMS Microbiol Rev 2001, 25:455-501.

96. Vignais PM: Hydrogenases and $\mathrm{H}(+)$-reduction in primary energy conservation. Results Probl Cell Differ 2008, 45:223-252.

97. Buhrke T, Lenz O, Porthun A, Friedrich B: The H2-sensing complex of Ralstonia eutropha: interaction between a regulatory [NiFe] hydrogenase and a histidine protein kinase. Mol Microbiol 2004, 51(6):1677-1689.

98. Angenent LT, Karim K, Al-Dahhan MH, Wrenn BA, Domiguez-Espinosa R: Production of bioenergy and biochemicals from industrial and agricultural wastewater. Trends Biotechnol 2004, 22(9):477-485.

99. Schut GJ, Adams MW: The iron-hydrogenase of Thermotoga maritima utilizes ferredoxin and NADH synergistically: a new perspective on anaerobic hydrogen production. J Bacteriol 2009, 191(13):4451-4457.

100. Rydzak T, McQueen PD, Krokhin OV, Spicer V, Ezzati P, Dwivedi RC, Shamshurin D, Levin DB, Wilkins JA, Sparling R: Proteomic analysis of Clostridium thermocellum core metabolism: Relative protein expression profiles and growth phase-dependent changes in protein expression. BMC Microbiol 2012, 12(1):214.

101. Chang T, Yao S: Thermophilic, lignocellulolytic bacteria for ethanol production: current state and perspectives. App/ Microbiol Biotechnol 2011, 92(1):13-27.

102. Guedon E, Desvaux M, Petitdemange H: Improvement of cellulolytic properties of Clostridium cellulolyticum by metabolic engineering. Appl Environ Microbiol 2002, 68(1):53-58.

103. Tripathi SA, Olson DG, Argyros DA, Miller BB, Barrett TF, Murphy DM, McCool $J D$, Warner AK, Rajgarhia VB, Lynd LR, et al: Development of pyrF-based genetic system for targeted gene deletion in Clostridium thermocellum and creation of a pta mutant. Appl Environ Microbiol 2010, 76(19):65916599.

doi:10.1186/1471-2180-12-295

Cite this article as: Carere et al.: Linking genome content to biofuel production yields: a meta-analysis of major catabolic pathways among select $\mathrm{H}_{2}$ and ethanol-producing bacteria. BMC Microbiology 2012 12:295.

\section{Submit your next manuscript to BioMed Central and take full advantage of:}

- Convenient online submission

- Thorough peer review

- No space constraints or color figure charges

- Immediate publication on acceptance

- Inclusion in PubMed, CAS, Scopus and Google Scholar

- Research which is freely available for redistribution 